\title{
Stratigraphic evolution of the Triassic-Jurassic succession in the Western Southern Alps (Italy): the record of the two-stage rifting on the distal passive margin of Adria
}

\author{
Fabrizio Berra, ${ }^{\mathrm{n}}$ Maria Teresa Galli, ${ }^{\mathrm{n}}$ Federico Reghellin, ${ }^{\mathrm{n}}$ Stefano Torricelli* and Roberto Fantoni* \\ "Dip. Scienze dellaTerra'A. Desio', Universita' degli StudidiMilano, Milan, Italy \\ *ENIS.p.A. Exploration \& Production Division, San Donato Milanese, Milan, Italy
}

\begin{abstract}
TheTriassic-Lower Jurassic succession of the Southern Alps is characterized by rapid thickness changes, from an average of about 5000m east of Lago Maggiore to about $500 \mathrm{~m}$ in theWestern Southern Alps.The stratigraphy refects the Triassic evolution of theTethyan Gulf and the Early Jurassic rifting responsible for the Middle Jurassic break-up of Adria from Europe.The succession of the Western Southern Alps starts with Lower Permian volcanics directly covered by Anisian sandstones. The top of the overlying Ladinian dolostones $(300 \mathrm{~m})$ records subaerial exposure and karstification. Locally (Gozzano), Upper Sinemurian sediments cover the Permian volcanics, documenting pre-Sinemurian erosion. New biostratigraphic data indicate a latest Pliensbachian- Toarcian age for the Jurassic synrift deposits that unconformably cover Ladinian or Sinemurian sediments. Therefore, in the Western Southern Alps, the major rifting stage that directly evolved into the opening of thePenninic Ocean began in the latest Pliensbachian-Toarcian. New data allowed us to refine the evolution of the two previously recognized Jurassic extensional events in the Southern Alps. The youngest extensional event (Western Southern Alps) occurred as tectonic activity decreased in the Lombardy Basin. During the Sinemurian the Gozzano high represents the western shoulder of a rift basin located to the east (Lombardy).This evolution documents a transition from diffuse early rifting (Late Hettangian-Sinemurian), controlled by older discontinuities, to rifting focused along a rift valley close to the Pliensbachian-Toarcian boundary. This younger rift bridges the gap between the Hettangian-Sinemurian diffuse rifting and the CallovianBathonian break-up. The late

Pliensbachian-Toarcian rift, which eventually lead to continental break-up, is interpreted as the major extensional episode in the evolution of the passive margin of Adria. The transition from diffuse to focused extension in the Southern Alps is comparable to the evolution of the Central Austroalpine during the Early Jurassic and of the Central and Northern Atlantic margins.
\end{abstract}

\section{INTRODUCTION}

Understanding of the complex processes related to the opening of new oceans has improved recently, thanks to the availability of new data from outcrops, seismic lines and wells. Seismic data and wells allowed researchers to detail the geometry of proximal to distal nonvolcanic passive margins mainly from the Central and North Atlantic (e.g., Withjack et al., 1998; Wilson et al., 2001; Schlische, 2003; Manatschal et al., 2007; Peron-Pinvidic et al., 2007; Tucholkeet al., 2007). The preservation of the architecture of a rift in outcrop is rare, but in a fewcases it is outstanding. This is the case for the distal passive margin of Adria preserved in the Swiss-Italian Alps (Florineth \& Froitzheim,1994; Manatschal \& Nievergelt,1997; Manatschal \& Bernoulli, 1999; Manatschal, 2004). Despite Alpine tectonics, most of the extensional structures are preserved. The margin of Adria is also well preserved in the Southern Alps of Italy, where extensional surfaces are less frequently exposed but the detailed geometric reconstruction of the extensional basins has been possible (i.e. Bernoulli, 1964; Bertotti et al., 1993; Bersezio et al., 1997; Fantoni \& Scotti, 2003). Integration of observations from 
seismic lines, boreholes and outcrops allowed identification of different stages of rift evolution before continental breakup (Lavier \& Manatschal, 2006; Manatschal et al., 2007). These include: stretching, thinning and exhumation. The transition from one mode to the next is controlled by the activation of new faults, cessation of tectonic activity on older faults and changes in fault geometry. Our understanding of the evolution from the rifting to the drifting stage in distal passive margins is based on a large amount of data.

Understanding of the stratigraphic evolution of rift deposits is limited by the small number of boreholes drilled through the entire sedimentary succession, from prerift to postrift deposits, and by the fact that the density of boreholes changes from proximal (higher)to distal(lower)parts of a passive margin. This has resulted in a lack of detailed stratigraphic descriptions and of high-resolution age constraints and correlations. Seismic lines provide detailed information on the present day geometry of rifted margins. In complex margins (i.e. Newfoundland-Galicia margin) seismic images indicate the presence of highs which separate basins with different architecture suggesting the existence of different tectonic provinces within the same margin (Manatschal, 2004).

As a consequence,correlation and dating seismic interpretations of synrift deposits in the different portions of extensional margins is difficult (Peron-Pinvidic et al., 2007). Examples of preserved and accessible early rifting successions are rare, as a result of their involvement in subsequent orogenic events and/or burial by younger sediments (e.g. Newark Basins). As a consequence, it is generallydi/cult to constrain the age of the onset of rifting and the duration/distribution of the syndepositional tectonics (Manatschal, 2004). The investigation of exposed synrift deposits is important in order to understand how the rifting process affected the different portions of a continental margin.

The Southern Alps of Italy is a favourable place to study the earliest stages of the evolution of a rift in time and space(i.e.Bernoulli,1964;Winterer\&Bosellini,1981).Mesozoic extension in this region was two-fold:(a)during the Triassic it was related to the westernmost Tethys gulf and (b) during the Early Jurassic it was controlled by processes related to the development of the western passive margin of Adria, which became convergent during the Late Cretaceous.

The successions of the Western Southern Alps (Cusio, Biella and Canavese zones; Fig. 1), situated between the Jurassic Penninic Ocean to the west and the thick successions of the Southern Alps to the east, record different events in the evolution of the sedimentary basin, reflected by important hiatuses and facies associations that significantlydiffer from those of the rest of the Southern Alps.

New biostratigraphic data from the synrift deposits of the Western Southern Alps, in conjunction with published data from the rest of the Southern Alps, allow us to define the ages and distribution of the main rifting stage, which led to the continental break-up of Adria.

\section{Geological setting}

The Mesozoic succession of the Southern Alps is characterized by rapid thickness and facies changes, which allow identification of roughly N-S-oriented paleogeographic domains bounded by discontinuously active syndepositional faults. Two main areas of subsidence are bounded by three relative highs (Bernoulli, 1964; Bosellini, 1973; Bertottietal.,1993).From west to east these are the Western Southern Alps (Cusio-Biella-Canavese zones), the Lombardy Basin, the Trento-Dolomites high, the Bellun oBasin and the Friuli Platform (Fig.1).The sedimentary successions of these five sectors record a first extensional event (Norian) that was responsible for important thickness changes of the Dolomia Principale and for the development of fault-controlled intraplatform troughs in the Lombardy Basin and the Carnian Prealps (Jadoul et al., 1992; Cozzi, 2000, 2002, and references therein). A second extensional event (early Early Jurassic) is characterized by the deposition of deep-water units in the Lombardy Basin and Belluno Through. On the Trento-Dolomites High, shallow-water facies (Calcari Grigi) persisted until the end of the Early Jurassic, when a general drowning was recorded.

The significance of the Norian tectonics is still matter of debate. According to Bertotti et al. (1993), it could represent the onset of the Jurassic rifting, whereas Bernoulli et al. (1990) consider it to be an older event. The stratigraphy of the upper Norian-Hettangian units is characterized in Lombardy bys hales and limestones. The initial input of shales(Riva diSolto Shale) smoothed the previous Norian topography, documenting the end of the faultcontrolled tectonics active during the Middle Norian(Berra\&Jadoul, 1996).The gradual recovery of carbonate production is recorded by the $\mathrm{Zu}$ Limestone (and equivalent units, such as the Tremalzo Limestone) which was deposited also on the Norian highs, where shales are less abundant (e.g. Brenta Dolomites). Within the Zu Limestone a marker bed ( $\mathrm{Zu}_{2}$ of Jadoul et al., 1994, 2004 deposited close to the Norian Rhaetian boundary) can be traced throughout the Lombardy Basin. The reduced thickness changes of this marker bed can be ascribed to the compaction of the underlying shales in the depressed areas. This continuous marker postdates the end of the tectonic extension 
in the Lombardy Basin. The Early Hettangian is characterized by a continuous carbonate platform (Dolomia a Conchodon, Corna, Lower Calcari Grigi) with constant thickness, which developed both on former Norian structural highs and basins. The presence of a period of tectonic quiescence (Late Norian?-Rhaetian-Hettangian) allows separation in time of the Norian and the Jurassic extensional events. These observations support, in our opinion, the hypothesis of Bernoulli et al. (1990) and are in contrast with the view of Bertotti et al.(1993). The presence of extension both in Lombardy and in the eastern Southern Alps suggests that the Norian tectonics could be controlled by events in the east (possibly related to the Tethys Ocean or to the Vardar-Meliata Ocean; Cozzi, 2000), far from the future Middle Jurassic break-up.

In the Lombardy Basin, the Triassic-Jurassic succession of the Southern Alps exhibits a thickness of about 5000m on average, that abruptly decreases toward the west (Western Southern Alps, Fig.1). In the western part, it is

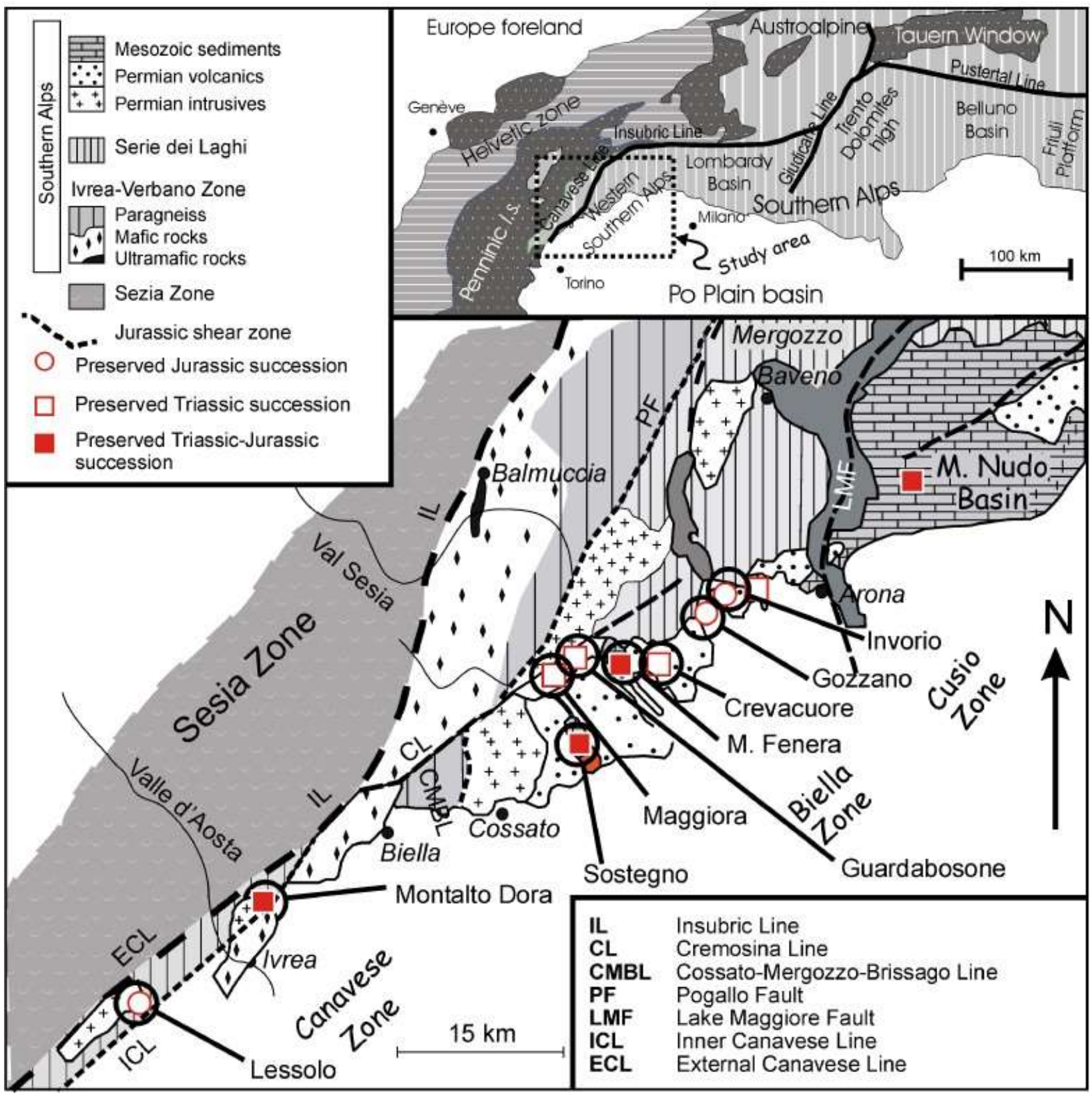

Fig.1. Geological setting of the Southern Alps and location of the study area.

represented by a 500m thick incomplete succession of Triassic to latest Lower Jurassic age (Fig. 2), which lies on 50$200 \mathrm{~m}$ of Lower Permian volcanics. The transition between thick and thin Mesozoic successions occurs with a roughly 
north-south-oriented, east-dipping syndepositional fault at the longitude of Lago Maggiore (Bernoulli, 1964; Klin \& $\operatorname{Tr}^{2}$ mpy,1977), which was mainly active during the Jurassic.

The sedimentary succession of the Western Southern Alps(west ofLagoMaggiore)canbe referredto three main zones, from east to west: the Cusio, the Biella and the Canavese zones (Figs1and 2).The Biella and Cusio zones were only slightly affected byAlpine tectonics (Zinggetal., 1976), buttheirMesozoic successionwas deeplyeroded.In the Canavese area the alpine metamorphism reached the epi-anchizone (Zingg et al., 1976) and the effects of the Alpine deformation were intense. In the Canavese zone the Mesozoic succession is preserved as tectonic slices along major faults (Biino \& Compagnoni, 1989; Ferrando etal., 2004). Although the preservation of Mesozoic rocks is discontinuous due to lateTertiary and Quaternary erosion, the successions of theWestern Southern Alps witness reducedsedimentationratestogetherwitherosionalevents, nondepositional stages and/oractive tectonics both during theTriassic and the Early Jurassic. Detailed reviews of the successions of the Western Southern Alps were published by Elter et al. (1966) and Sturani (1975), who suggested a connection between the Canavese and the pre-Oligocene successionoftheMonferratoandwiththe easternLigurian units of the Northern Apennines. Ferrando et al. (2004) focused on the petrography of the Canavese basement 


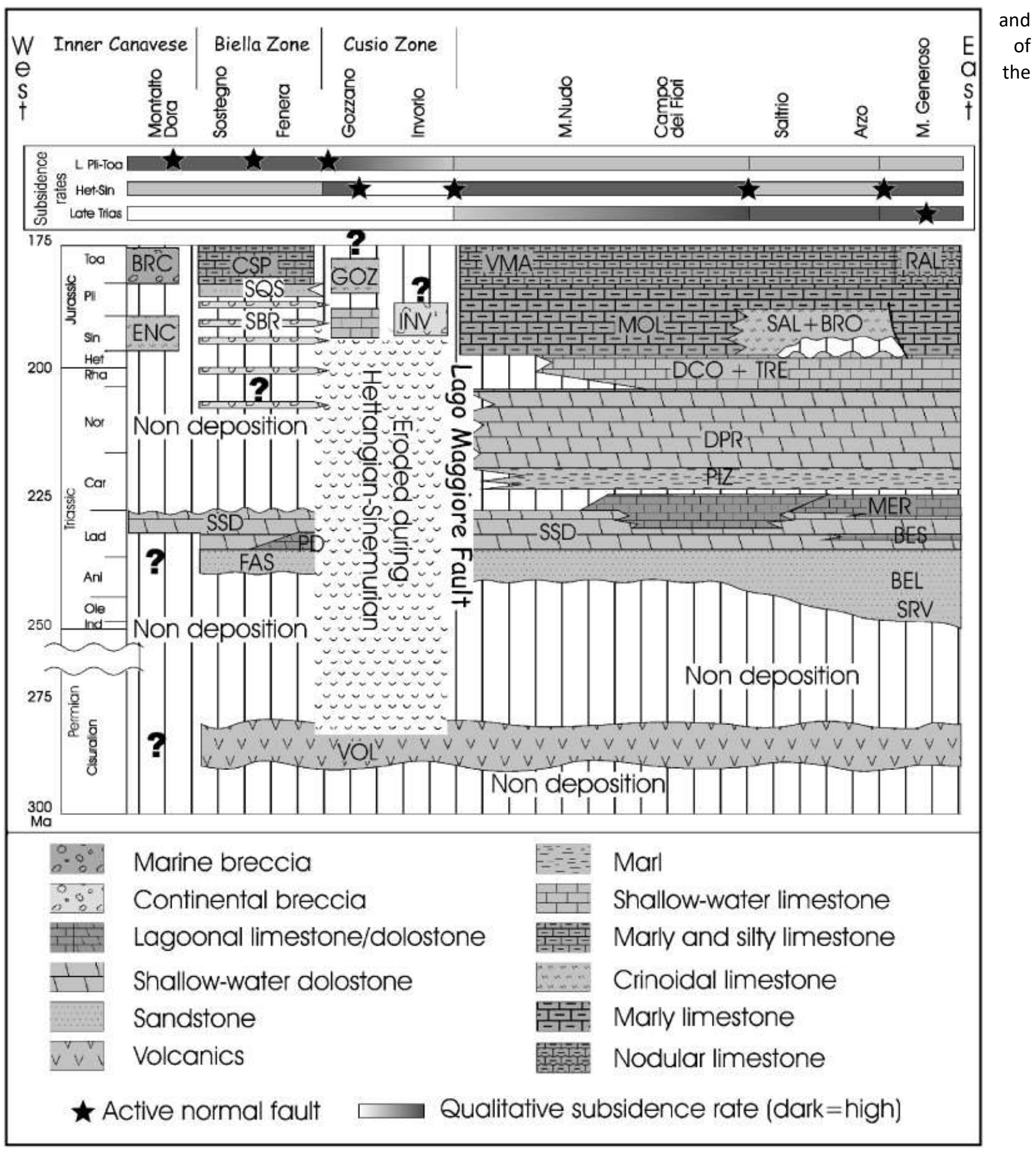

Fig. 2. Chronostratigraphic scheme of the Permo -Jurassic succession of the Western Southern Alps. Abbreviations in alphabetic order.

BEL, Bellano Formation; BES, Besano Formation; BRC, Marine breccias ; SBR, Sostegno Breccia; CSP, 'Calcari Spongolitici'; DCO1TRE, 'Dolomia a Conchodon' and Tremona Series ; DPR, Dolomia Principale ; ENC, Sinemurian encrinites ; FAS, FeneraAnnunziata Sandstone ; GOZ, Gozzano succession; INV, Invorio Breccia; MER, Meride Limestone ; MOL, Moltrasio and Domaro Limestone ; RAL, Rosso Ammonitico Lombardo; SAL1BRO, Saltrio Fm. and 'Broccatello'; SQS, San Quirico Sandstone ; SRV, 'Servino'; SSD, San Salvatore Dolomite ; VMA,Valmaggiore Fm.; VOL, Permian volcanics.

Jurassic clastic deposits, substantiated the role of the Canavese zone as the distal margin of Adria during the Jurassic opening of the Penninic Ocean, previously suggested by other authors (i.e. Bertotti etal.,1993). 


\section{Mesozoic stratigraphyof theWestern Southern Alps}

Our detailed stratigraphic and biostratigraphic analyses have been carried out in the Biella zone of the Western Southern

Fig. 3. Stratigraphic sections of the Jurassic successions at Monte Fenera and Sostegno, with the distribution of the dinoflagellate cyst species. See Fig. 1 for location.

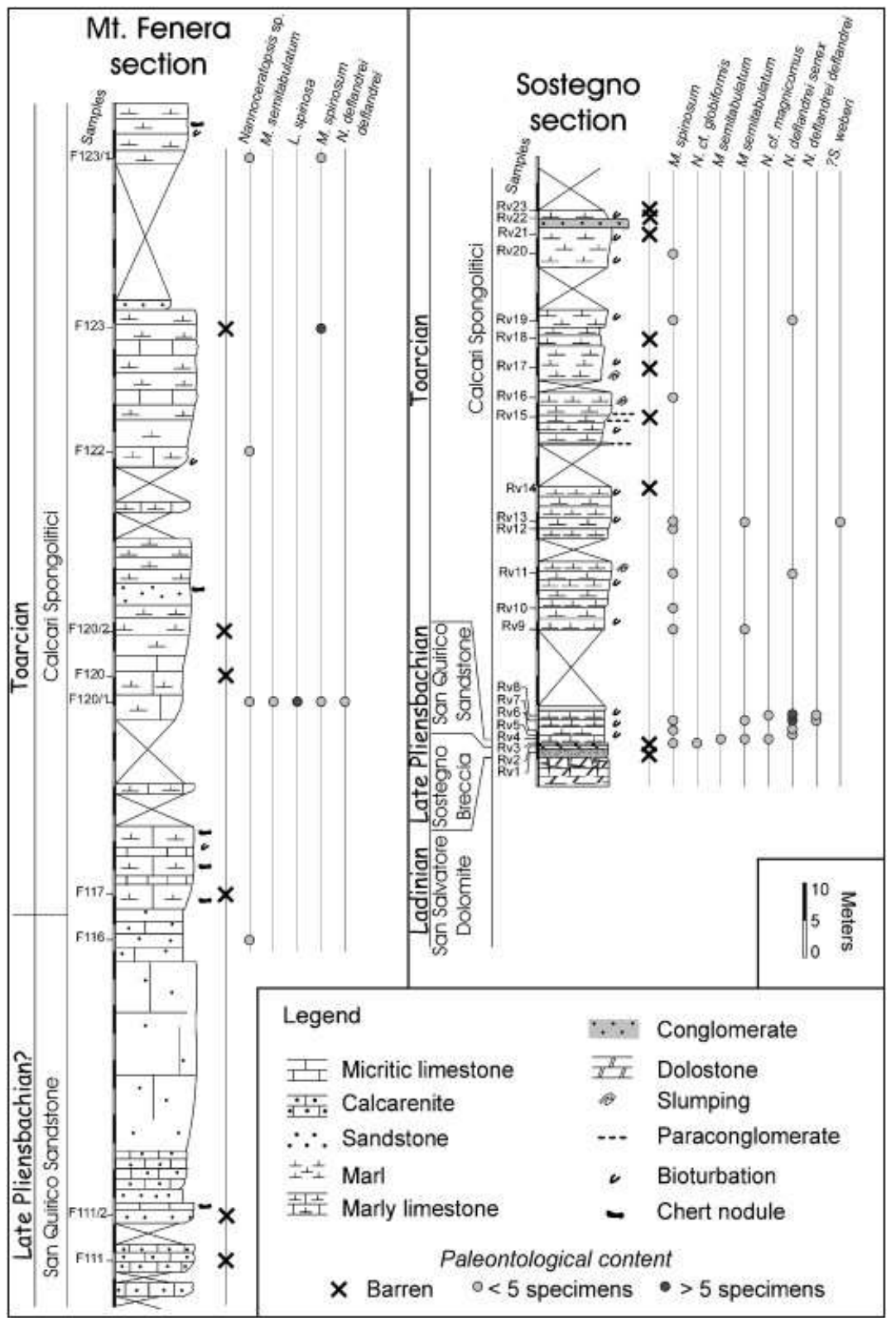

Alps, where the successions are only slightly affected by the Alpine tectonics. Only two sections (Monte Fenera and Sostegno; Fig. 3) range from the Permian to the Jurassic, whereas the other successions are characterized by the preservation of Permo-Triassic only, because of later erosion, or, in turn, only Jurassic rocks, due to pre-Jurassic events (Figs1and 2). Field observations from the Cusio zone (Gozzano, Invorio) and the Canavese zone (Montalto Dora) have been compared with the data available form the literature.Everywhere,theMesozoic succession is highly incomplete and the following stages, divided by a major hiatus (Late Triassic-Early Jurassic), are recorded in the Mesozoic succession.

MiddleTriassic succession

The Lower Permian volcanics are directly covered by 1-3m thick shallow-water sandstones(FeneraAnnunziata Sandstone; Fantoni et al., 2003). This unit corresponds to the Bellano Formation of Gaetani (1982) and theVal Muggiasca Sandstone of Farabegoli \& De Zanche (1984). At Sostegno thin tuff layers are present within this unit (Carraro\&Fiora,1974). The 
Fenera Annunziata Sandstone is overlain by a few meters of darkdolostones (Pissone Dolomite, Monte Fenera) or directly by light-grey fine grained dolostones (Sostegno), which represent the typical facies of theMiddleTriassic of theWestern Southern Alps (San Salvatore Dolomite). This latter unit, about 300m thick, consists of monotonous stromatolitic and micritic dolostones, locally bedded. The Triassic units (Fenera Annunziata Sandstone, Pissone Dolomite and San Salvatore Dolomite) were deposited during Late Anisian and Ladinian times. The occurrence of palynomorphs such as Sellaspora foveorugulata and Deltoidospora minor in the upper part of the Pissone Dolomite indicates a Late Anisian to Ladinian age for the basal, dark dolostones. Both the palynomorphs and calcareous algae assemblages (Farabegoli \&DeZanche,1984;Fantonietal., 2003,respectively)indicate a Late Anisian (Illyrian) age for the marine transgression above the Early Permian volcanics. The finalon se tof the carbonate platform interior environment of the San Salvatore Dolomite likely occurred atthe base of the Ladinian.

The Upper Anisian-Ladinian succession is characterized by constant thickness and by the absence of important facies changes. This homogeneous stratigraphic setting indicates the absence of a significant syndepositional tectonic activity in the Biella zone during the Middle Triassic.

The succession in the Canavese zone is strongly displaced by Alpine faults and preserved as minor tectonic slices. Nevertheless, where preserved (i.e. Montalto Dora) the stratigraphy of theTriassic succession closely resembles that of the Biella zone (Sturani, 1975; Ferrando et al., 2004).

\section{LateTriassic-early Jurassic hiatus}

The Jurassic sediments unconformably cover the underlying units (Fig. 2). The Canavese, Biella and Cusio zones can be defined by the unique relationships of each zone between Jurassic and older successions. The eastern boundary of the Cusio Zone with the more rapidly subsiding Lombardy Basinis abrupt, as documented by the rapid changes in thickness and facies of the Triassic succession across the Lago Maggiore Fault (Bernoulli,1964).

In the Western Southern Alps it is possible to identify (1)successions with preserved pre-Jurassic rocks(Canavese and Biella zones) and (2) successions where preJurassic rocks have been exposed before the deposition of the Jurassic sediments, which locally lie directly on the Permian volcanics (Gozzano and Invorio, Cusio Zone) or on basement rocks (Canavese Zone).

In the first case (Sostegno, Fenera), the hiatus is invariably markedbythe occurrence ofdolomitic brecciaswith a reddish matrix (Sostegno Breccia, containing clasts from a few to some tens of centimetres in size, exclusively derived from the San Salvatore Dolomite)(Figs4a,c and5a,b).The red dolomitic sediments penetrate into the carbonate facies of the San Salvatore Dolomite for up to $15-20 \mathrm{~m}$ and the abundance of breccia-filled sedimentary dykes decreases from the top of the unit downward. The Sostegno Breccia is a product of karstification at the top of the Ladinian platform. We considered two hypotheses for the age and duration of the karst event: (1) the Upper Triassic rocks were deposited and subsequently eroded before the deposition of the Lower Jurassic rocks or (2) they were not deposited and the succession of the westernmost Southern Alps remained emergent during the Late Triassic. The thickness of the Ladinian succession, when capped by this karst surface, is the same everywhere. Additionally, the clasts o fthe overlying breccias are derived only from the San Salvatore Dolomite lithologies. The total absence of Upper Triassic sediments (both in outcrop and as clasts in younger sediments) supports the hypothesis that they were not deposited.

In the Cusio zone, the deposition of Jurassic sediments occurred after an erosional stage, documented by the partial or total absence of the Middle Triassic carbonate sediments. Upper Sinemurian carbonates directly overlie the Permian volcanics at Gozzano (Fig. $5 \mathrm{~g}$ ). The presence of corals and crinoids suggests deposition on a paleohigh probably within the photic zone (the paleodepth can be compared with that of the Broccatello; Neuweiler \& Bernoulli, 2005). At Invorio, poorly sorted, clast-supported angular breccias(Fig.4d) are interpretedas continental deposits of Jurassic age (Casati,1978). The Gozzano succession records a pre-Sinemurian major erosional event.The occurrence of an erosional event associated with an angular unconformity close to the Hettangian-Sinemurian boundaryis also recorded in the Monte NudoBasin(Klin \& Trmpy,1977; Jadoul et al., 2005 and references therein).

To the west (Canavese),Jurassic sediments directly overlie the Middle Triassic dolostones or are preserved within sedimentary dykes, which cut Middle Triassic facies. The presence of dolostones with a 'Norian Hauptdolomit facies' has been suggested, but not documented, by Sturani (1975). A Toarcian age of the sedimentary dykes is suggested by the pelagic bivalves (Baggio, 1965) and by the age of the youngest rocks preserved in the dykes (Sturani, 1975). 
Locally, Jurassic breccias (Levone and Bric Filia; Sturani, 1975, of inferred Middle Jurassic age) with basement clasts lie on the Variscan intrusive bodies. This contact is interpreted as evidence of onlap of submarine deposits on basement rocks that were exhumed along low-angle detachments during Jurassic rifting (Ferrando etal., 2004).

\section{The lower Jurassic succession}

In the more rapidly subsiding areas (Mt. Fenera and Sostegno;Biellazone), where the Middle Triassic succession is preserved (Fig. 3), Jurassic sedimentation started with lithic sandstones rich in clast of dolostones, Permian volcanics and, less frequently, basement clasts (Figs $4 b$ and 5c, e; San Quirico Sandstone). At the base of the succession, sedimentary structures (cross and hummocky cross stratifications)indicate deposition in a shallow-water setting. The succession evolvedto deeper-watersediments (correspondingtotheValmaggioreFm.in theMonteNudo Basin; Klin \& Trmpy, 1977) which consist of marls and turbiditic sandstones (Fig. 4f), locally including chert nodules ('Calcari Spongolitici', Carraro \& Sturani, 1972; Fantoni etal., 2003). At the base of the succession, glauconite grains (probably parautochthonous, sensu Amorosi, 1997) commonly occur within the lithic sandstone (Fig. 5c). The Mt. Fenera and Sostegno sections evolved slightly differently. At Sostegno the cross-laminated inner neritic sandstones reach a thickness of about $3 \mathrm{~m}$ and are directly covered by burrowed marly limestones which locally include slumps and/or paraconglomerate beds (Fig. 4e). At M. Fenera the shallow-water sandstones are thicker (about 30-40m) and are covered by a more than $100 \mathrm{~m}$ thick succession of turbidite sandstones with interbedded spongolitic limestones (Fig. 5d) followed by marls. Erosion of emerged structural highs occurred during the deposition of the deep-water spongolitic limestones and marly limestones. Subaerial erosion is documented by the presence of normally graded sandstones and conglomerates with pebbles of basement, Permian volcanics and Triassic dolostones (Sostegno; Figs 4h, i and5f), containing wood fragments up to afewcentimetre in size (Fig. 4g). The subaerial exposure in the Cusio zone is also suggested by the breccias and conglomerates of the Invorio Breccia(Casati,1978). The Invorio Breccia consists of angular clasts mostly of dolomitic and volcanic rocks with minor basement component and is interpreted as a continental deposit of inferred Jurassic age (Fig. 4d). At Gozzano (Montanari,1969) the Jurassic succession directly overlies the Permian volcanics, indicating partial or total erosion of the Triassic succession before Late Sinemurian(the presence ofsome remnants oftheTriassic succession is documented in some wells; A. De Carlis, pers. comm.). Here, two different Jurassic facies are preserved (Sacchi Vialli \& Cantaluppi, 1967; Montanari, 1969). An angular unconformity separates the upper Sinemurian-lower Pliensbachian (?) inner to middle neritic carbonate facies from upper Pliensbachian (middle- upper Domerian) crinoidal limestones (rich in volcanic clasts), bioclastic limestones, and nodular marly limestones(Fig.5h).UpperPliensbachiansedimentsfillneptunian dykes in the upperSinemurian succession. The facies assemblages indicate that the deposition occurred on a submarine highand resemble those oftheBroccatelloFormation of the Arzo High (Wiedenmayer, 1963; Bernoulli, 1964; Klin \& Trmpy,1977; Jadoul etal., 2005; Neuweiler \& Bernoulli, 2005), which borders the Monte Generoso Basin. The sedimentary succession of Gozzano therefore records two depositional events, a first of late Sinemurian age and a second, of late Pliensbachian age. These were most likely a response to significant synsedimentary tectonic activity. 

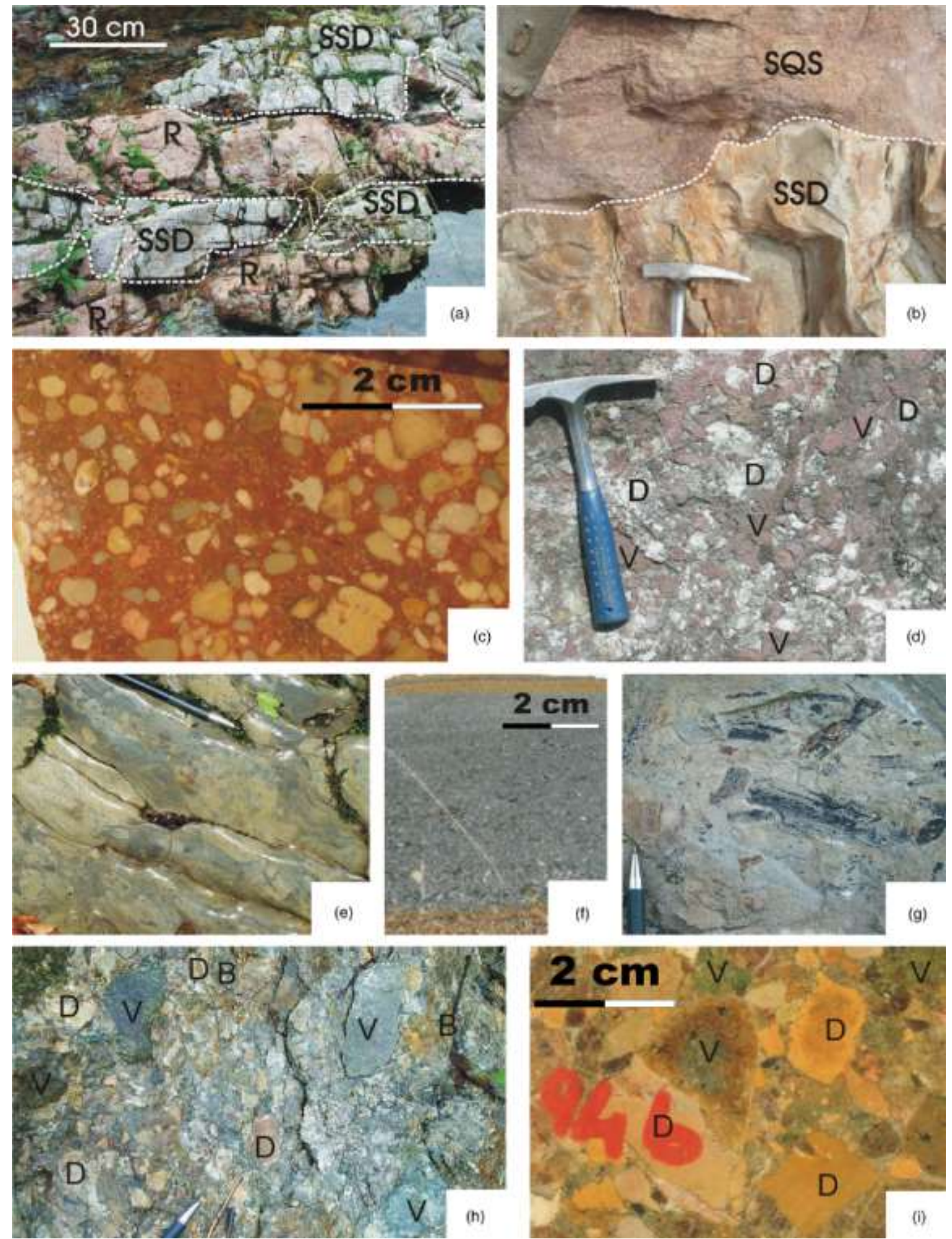

Fig.4. Aspects of theTriassic and Jurassic succession of Monte Fenera and Sostegno (a) Sostegno Breccia: dykes of red dolostones (R) cutting the Ladinian San Salvatore Dolomite (SSD); (b) Contact between the Ladinian San Salvatore Dolomite

(SSD) and the San Quirico Sandstone (SQS); (c) Detail of the Sostegno Breccia (polished slab): all clasts are from the San Salvatore Dolomite; (d) Invorio Breccia, containing angular clasts of San Salvatore Dolomite (D) and Permian volcanics (V); (e) Paraconglomerate in the late Pliensbachian?-Toarcian Calcari Spongolitici at Sostegno; ( $f$ ) Graded turbititic calcareous bed, Calcari Spongolitici (Toarcian) at Sostegno, polished slab; (g) Wood fragments within the turbiditic sandstone of theToarcian Calcari Spongolitici at M. Fenera; ( $h$, i) Conglomeratic body interbedded in theToarcian Calcari Spongolitici at Sostegno ( $h$, outcrop; i, polished slab): note the presence of dolomitic clasts (D), basement (B) and Permian volcanics (V). 
In the deformed succession of the Canavese zone, the Ladinian dolostones (Montalto Dora; Baggio, 1965) are covered by breccias, capped by cherty dolostones and marls. Locally, schists of possible Middle Jurassic age are present (Lessolo; Biino \& Compagnoni,1989; Ferrando et al., 2004).

Evidence of late Pliensbachian-Toarcian tectonics and exposure of the Variscan basement is also recorded in the Canavese zone in the form of breccias with basement clasts whichwere deposited above Permian granites, along with sedimentary dykes which can be traced upward to marls and chert likely of Toarcian age (Sturani,1975). Erosion in the Canavese Zone is probably related to exhumation along normal faults of the Variscan basement during the extension related to the rifting (Ferrando et al., 2004). Tectonics was active at least until the Middle Jurassic, as suggested byolistoliths ofTriassic dolostones andgranites within the Middle Jurassic Levone Shale. Late Jurassic radiolarites containing rare pebbles of granites directlylie on the granites. The youngest preserved rocks in theWestern Southern Alps crop out in the Canavase zone.They consist of Late Tithonian-Berriasian pelagic limestones (Maiolica; Baggio,1963) characterized by intercalations of turbidite sandstones, capped by shales and argillaceous limestones (Argille a Palombini, the equivalent of the Bruntino Marl in the Lombardy Basin) that are probably Early Cretaceous in age.

\section{Biostratigraphy of the Lower Jurassic succession of the Biella Zone}

Despite the scarce preservation of the Jurassic sedimentary cover, the Biella zone is a key area for the reconstruction of the timing of a major extensional event along the future passive margin of Adria. The most complete sections crop out at Monte Fenera and Sostegno, where scarce biostratigraphic constraints have been found previously.In the Sostegno section, Toarcian ammonites are reported from the middle part of the section (Carraro \& Sturani, 1972). At Monte Fenera the presence of ammonites (probably late Pliensbachian)was reportedbyRasetti(1897).The determination of the age of the sediments deposited after the hiatus between the MiddleTriassic and Jurassic successions is crucial for the reconstruction of the evolution of the Western Southern Alps during the Early Jurassic, as their deposition records important episodes of syndepositional tectonic activity. Two stratigraphic sections have been measured and sampled in this study (Fig. 3). Samples have been successfully processed for the study of palynofacies and dinoflagellate cysts (Fig.6).

Fig.5. Microfacies of the Jurassic succession of the Western Southern Alps. Scale bar is $2 \mathrm{~mm}$ for all pictures. (a) Karstic breccias (Sostegno Breccia) at the top of the Ladinian San Salvatore Dolomite, sample SO6, Sostegno; (b) Monogenic finegrained conglomerate (Sostegno Breccia, clasts form San Salvatore Dolomite) at the top of the Ladinian platform at M. Fenera (sample F 58); (c) Basal sandstone of the San Quirico Sandstone at Sostegno, (sample F 105). Note the presence of lithoclasts from the Permian volcanics (V) and rare glauconite grains (G); (d) Bioclastic packstones with spiculae and echinoids, with rare lithic clasts of Permian volcanics (V). Monte Fenera, sample F 112; (e) S. Quirico Sandstone, rich in fragments of Permian volcanics (mainly ignimbritic flows). Monte Fenera, sample F105; ( $)$ Coarse sandstone within theToarcian Calcari Spongolitici: note the abundance of fragments of Permian volcanics, sample S 95; (g) Large bivalve shells within a sandy limestone characterized by the presence of fragments of Permian volcanics ; Upper Sinemurian succession at Gozzano, sample G 5; (h) Bioclastic wackestone rich in sponge spiculae, echinoids, foraminifera and small ammonites. Presence of lithoclasts from the Permian succession (V). Late Pliensbachian deposits at Gozzano, sample G 11. 

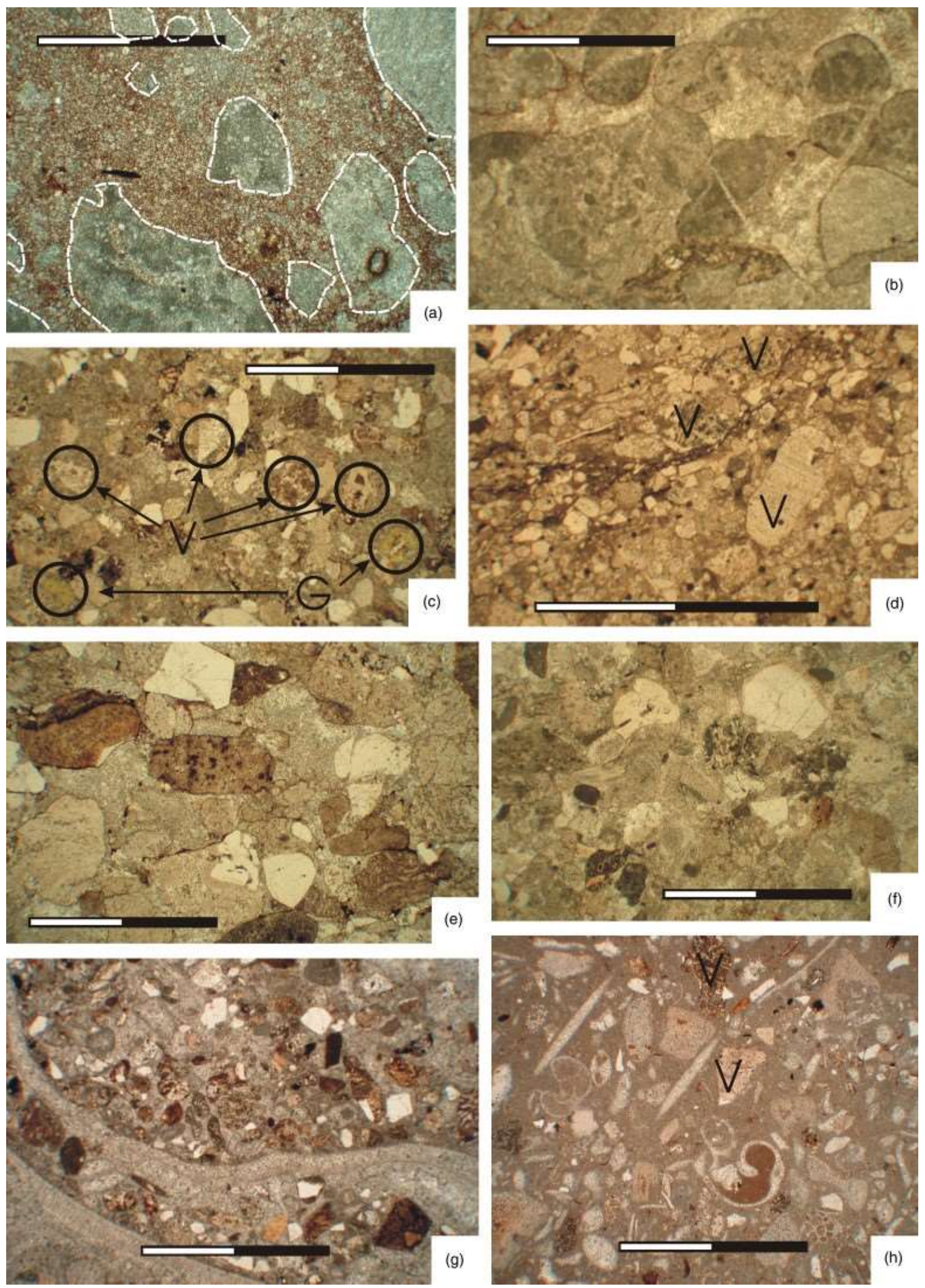


\section{MATERIALS AND METHODS}

Thirty-one samples(21fromSostegno section and10from MonteFenera section)were collected from shales and siltstones. The samples were prepared following standard palynological techniques (Wood et al., 1996) and analysed using transmitted light microscopy. The slides were scanned in full. The palynomorph assemblages are comprised of pollen, with limited biostratigraphic resolution (including Classopollis and Cerebropollenites, trilete spores, Tasmanites), dinoflagellate cysts, acritarchs and microforaminiferal test linings. Owing to their biochronostratigraphic importance, only organic-walled dinoflagellate cyst assemblages will be discussed. Light photomicrographs were taken using a Zeiss Axioplan microscope and interference contrast illumination (Fig.6).

\section{Biostratigraphy of the Sostegno section}

Eight dinoflagellate cysts pecies have been identified in the Sostegno section (Figs 3 and 6). They occur most frequently in the lowermost part of the section (San Quirico Sandstone and lower part of Calcari Spongolitici, Fig. 3). The genus Nannoceratopsis is represented by the (sub)species N. deflandrei senex, N. deflandrei deflandrei (Fig. $6 \mathrm{i}$ and j-I), N. cf. magnicornus, N. cf. globiformis, Nannoceratopsis cf. ambonis (Fig.6e). In particularN.deflandrei senex (Fig.6f-h) is abundant in samples RV 7 and RV 8, whereas it almost disappears from sample RV 9 upwards. The first occurrence of $\mathrm{N}$. deflandrei senex was documented in the earliest Pliensbachian jamesoni ammonite zone of Portugal (Bucefalo Palliani \& Riding,1999) and its last occurrence in the Tethyan Realm was calibrated in theToarcian bifrons ammonite zone (Davies,1985).

N. magnicornus and N. globiformis have been previously reported only from the latest Pliensbachian spinatum ammonite zone ofsouthwestFrance(BucefaloPalliani\&Riding,1997).Specimens found here(Fig.6a)arevery rare and their morphology is not entirelyconsistentwith those observed in SW France.

Although the genus Nannoceratopsis probably originated in theTethys, it migrated northwards in the late Pliensbachian and thrived in the Boreal Realm (Bucefalo Palliani \& Riding,1999), as documentedbyits consistent presence in the fossil record from northwest European sections (Woollam \& Riding, 1983; Riding \& Thomas, 1992). Conversely, Nannoceratopsis is absent in the southern Tethyan sections of central Italy and Greece (Bucefalo Palliani \& Riding, 1997,1999, 2003), thuss hawing a clear paleolatitudinal partition. Therefore our findings not only document the first observation of this taxon in Italy, but also increase the southernmost extent of the paleogeographic distribution of the genus Nannoceratopsis in theTethyan Realm.

Although rare, Mendicodinium spinosum (Fig. $6 c$ and d) is found fairly continuously throughout the Sostegno section. This species was described from the Early Toarcian of central Italy (BucefaloPallianietal.,1997)but it was also found in the Pliensbachian of Greece, Hungary and Portugal. In theTethyan domain the first occurrence of the Mendicodinium group marks the base of the Pliensbachian stage (Bucefalo Palliani \& Riding,1997, 2003).

Three specimens, questionably assigned to Scriniocassis weberi due to poor preservation, were detected in sample RV 13 (Fig. 60 and p). The stratigraphic distribution of S. weberi is well documented in the Boreal Realm and extends from the late Pliensbachian margaritatus ammonite zone upwards to the Aalenian-Bajocian boundary. The same stratigraphic distribution is proposed in the Tethyan Realm on the basis of data from Portugal (Davies, 1985; Bucefalo Palliani \& Riding, 2003).

\section{Biostratigraphy of Monte Fenera section}

Sample F120/1P, collected from the upper part of the Calcari Spongolitici sampled at theM.Fenera sectionyielded some specimens of Luehndea spinosa associated with Mancodinium semitabulatum (Fig. 60 and p). Luehndea, like Nannoceratopsis, is a cosmopolitan taxon that originated in the Tethyan domain in the earliest Pliensbachian and migrated during the Pliensbachian into the Boreal Realm where it reached its highest abundances becoming dominant in the dinocyst assemblages(BucefaloPalliani\&Riding,1999, 2003;Poulsen\&Riding, 2003).This is supported by the stratigraphic ranges for L. spinosa.This species was restricted to the margaritatus, spinatum and tenuicostatum ammonite zones in the Boreal Realm and spans the entire Pliensbachian plus the earliest Toarcian tenuicostatum ammonite zone in theTethyan Realm (Bucefalo Palliani \& Mattioli, 1998; Bucefalo Palliani \& Riding, 1999, 2003). 

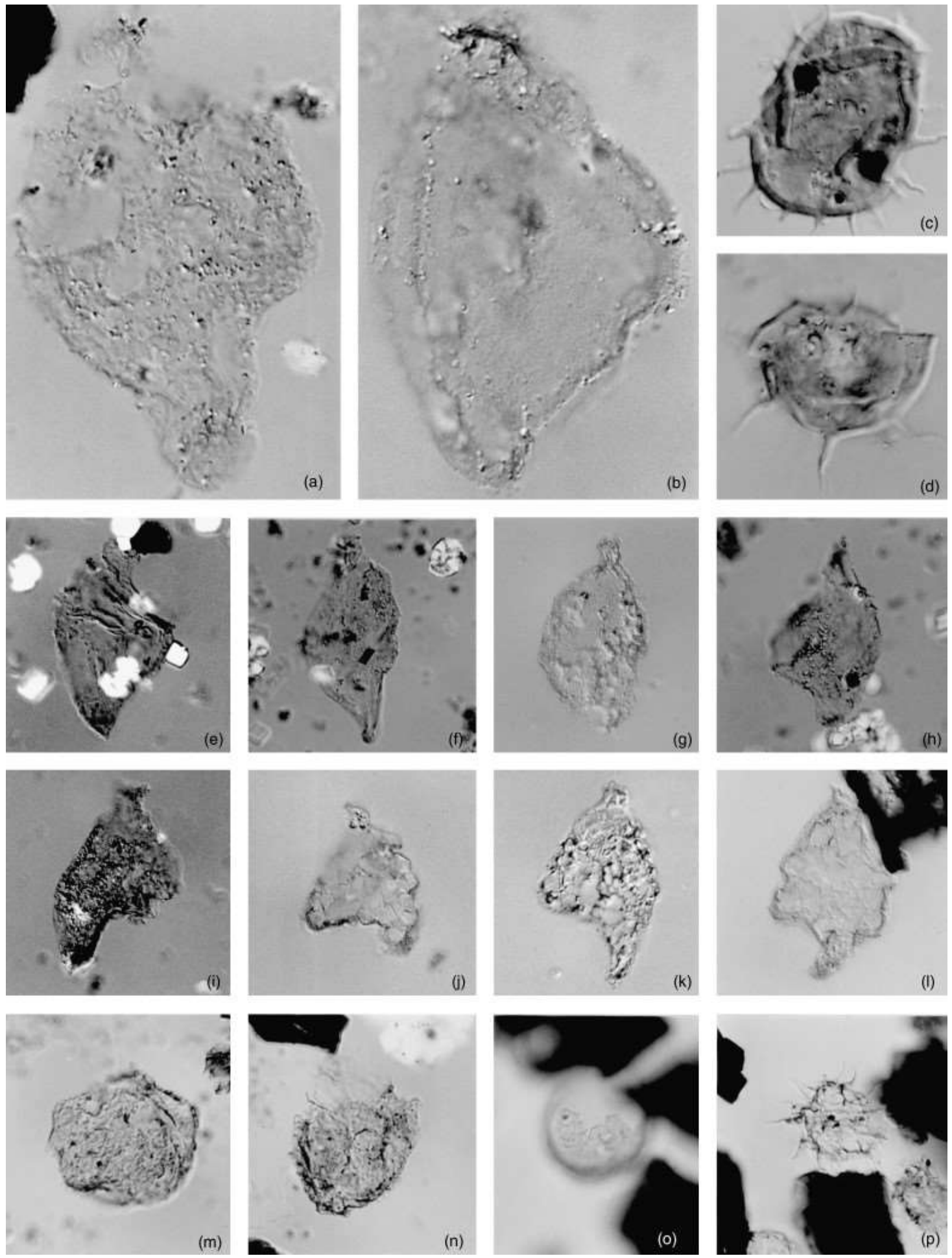

Fig.6. Dinoflagellate cysts from the Sostegno and Monte Fenera sections. Magnifications 550 unless otherwise stated (EFG,

England Finder Coordinates). (a) Nannoceratopsis magnicornus x1375, sample RV 8, EFC P36/1; (b) Nannoceratopsis deflandrei senex x1375, sample RV 7, EFC G28; (c) Mendicodinium spinosum x1375, sample RV 16, EFC S53/1; (d) Mendicodinium spinosum x1375, sample RV 13, EFC H50/2; e) Nannoceratopsis cf. ambonis, sample RV 8, EFC H21; (f ) Nannoceratopsis deflandrei senex, sample RV 8, EFC Q29/4; (g) Nannoceratopsis deflandrei senex, sample RV 7, EFC G48; (h) Nannoceratopsis deflandrei senex, sample RV 8, EFC J30/1; Nannoceratopsis deflandreideflandrei, sample RV 8, EFC H21; Nannoceratopsis deflandreideflandrei, sample RV 7, P59; (k) Nannoceratopsis deflandrei deflandrei, sample RV 7, EFC D56/1; (I) Nannoceratopsis deflandreideflandrei, sample RV 4, EFC R39/1; (m) Scriniocassis weberi, sample RV 13, EFC Y37/1; (n) Scriniocassis weberi, sample RV 13, EFC F42/1; (o) Mancodinium semitabulatum, sample FP 120/1P III, EFC Y 17/1; (p) Luehndeaspinosa, sample FP 120/1P III, EFC T17. 
In the Western Southern Alps (Sogno Formation, Lombardy Basin) a Luehndea spinosa abundance episode has been recorded in the Carinolithus superbus Nannofossil Zone NJT6 (Mattioli \& Erba, 1999) of Early Toarcian age.

In contrast, the inception ofM.semitabulatum is synchronous in the Boreal and Tethyan Realms at the SinemurianPliensbachianboundary.As the known range ofthis species extends into the Bajocian, its occurrence does not help to constrain the age of the samples investigated here. The composition of the assemblages, comprising both Boreal elements (Luehndea and Nannoceratopsis) and Tethyan forms (Mendicodinium), fits with the sub-Mediterranean bioprovince delineated by Bucefalo Palliani \& Riding (1999) within the northern Tethyan Realm on the basis of data from Portugal and southern France. In contrast, the Mediterranean bioprovince, defined within the southernTethys on the basis of data from central Italy and Greece, is characterized bythe lack of the genusNannoceratopsis and higher abundances of Mendicodinium.

In sum, dinoflagellate cysts indicate a Pliensbachian to earliest Toarcian age for the sediments under investigation. If the identification of $\mathrm{S}$. weberi and $\mathrm{N}$. magnicornus is correct, it would narrow the age assignment to the late Pliensbachian-earliest Toarcian interval. Furthermore, considering that Mendicodinium spinosum in central Italy has been reported only from the lower Toarcian, the deposition of the Calcari Spongolitici in the Sostegno succession likely began in the early Toarcian. In the Sostegno section the Toarcian age of the middle-upper part of the Calcari Spongolitici is documented by ammonites (Carraro \& Sturani, 1972). The age of the Jurassic succession at M. Fenera could be slightly younger, but no fossils have been observed in the basal portion of these sections.

\section{DISCUSSION}

\section{Evolution of the sedimentary succession of the Western Southern Alps}

The sedimentary succession of the Canavese, Biella and Cusio zones differs markedly from that of the rest of the Southern Alps. Marine sedimentation began during Late Anisian, whereas in the central and easternSouthernAlps the first regional transgression dates back to the Induan. In the Western Southern Alps theTriassic succession is thinner and only Upper Anisian and Ladinian rocks were deposited. Subaerial exposure of the Ladinian platform likely persisted until the Early (Montalto Dora, Canavese zone) to Late Sinemurian (Gozzano, Cusio zone) or latest Pliensbachian-Toarcian in the Biella zone (M. Fenera, Sostegno). Until the end of theTriassic, the study area representedthe innermost and minimall ysubsiding portion of the Permo-TriassicTethys gulf, facing the open sea to the east.The Norian extension recorded in the Lombardy Basin(Jadouletal.,1992)and in theCarnicAlps(i.e.Cozzi, 2002) is not documented here.

In the Western Southern Alps the uplift and erosion of the Gozzano High occurred before its drowning, in the Late Sinemurian (Montanari, 1969). During the uplift of the Gozzano High (Sinemurian p.p.), subsidence in the Lombardy Basinwas responsible for the drowning of a complex horst and graben paleotopography (e.g. Bertotti et al., 1993 and references therein), where thick wedges of turbiditic marly limestones were deposited. The Biella succession, west of the Gozzano high, did not record the Hettangian uplift and shows no evidence of Sinemurian sedimentation. Further to the west, in the Canavese zone, a badly preserved ammonite found in the crinoidal limestones (Montalto Dora, Sturani, 1965) indicates an early Sinemurian age for the return to sedimentation after post-Ladinian subaerial exposure. The crinoidal limestones(which couldbe a counterpart of the coeval Saltrio Limestone deposited east of the Lake Maggiore) record the drowning of the previously emerged Ladinian carbonate platform.

Neptunian dikes crossing the Sinemurian successions at Gozzano and in the Canavese Zone (Montalto Dora) along with the presence of the angular unconformity between the upper Sinemurian and upper Pliensbachian units at Gozzano (Montanari,1969) reflect the occurrence of a post-Late Sinemurian and pre-Late Pliensbachian uplift followed by subsidence.

The petrography of the San Quirico Sandstone (Late Pliensbachian-Toarcian), the sedimentary structures and the presence of abundant wood fragments within the Calcari Spongolitici and interbedded conglomerates suggest the existence of nearby emerged lands where the Permian Volcanics and Variscan basement was subaerially exposed. The San Quirico Sandstone is thicker at Mt. Fenera than at Sostegno, suggesting that the emerged lands were located in the Cusio Zone.

Close to the Late Pliensbachian-Toarcian boundary, rapid subsidence is recorded all over the Western Southern Alps by the transition from emerged lands or shallow successions to deep water turbiditic units. Upper PliensbachianToarcian sediments unconformably lie on middle Triassic or Sinemurian rocks. In the Canavese Zone Middle Jurassic 
sediments (Levone Breccia; Sturani, 1975) were deposited directly on basement highs. The presence of sediments on basement highs is controlled by different processes in the Cusio and Canavese zones. In the Canavese zone (distal part of the Adria passive margin) the deposition of deep-water sediments is younger (Middle Jurassic) and related to exhumation of basement along low-angle detachments (Ferrando et al., 2004) during the exhumation stage (Manatschal, 2004). In contrast, in the Cusio Zone, the deposition of sediments on basement highs occurred earlier and was associated with subaerial erosion. At Sostegno and M. Fenera sedimentation started in the tectonic depressions (grabens) where sandstones directly cover the Sostegno Breccias which marks the subaerial emergence of the top of the Ladinian carbonate platform. Differences in sedimentation rates from the M. Fenera and Sostegno sections denote the persistence of syndepositional tectonic activity, at least until the end of the Early Jurassic.

The available data allow us to reconstruct the distribution, in time and space, of erosion and sedimentation in the Western Southern Alps. During theTriassic, the Western Southern Alps played the role of the western margin of the more rapidly subsiding Lombardy Basin, as documented by non-deposition and karstification of the Ladinian carbonate platform. The uplift of the Cusio zone (Gozzano, Invorio) reflects its role as the western shoulder of the Monte Nudo basin during the Late Hettangia nSinemurian rift of the Lombardy Basin.

\section{Tectonic evolution}

The Late Triassic-Early Jurassic successions in the Southern Alps reflect the well-know Early Jurassic rifting stage that affected the western and northern borders of Adria (i.e. Bernoulli et al., 1979; Winterer \& Bosellini, 1981; Bertottietal.,1993).In detail, different extensional stages(stratigraphically recorded by facies distribution and rapid thickness changes across syndepositional faults) that occurred at different times across the Southern Alps have been identified (i.e. Bertotti et al., 1993). In the Lombardy Basin the maximum tectonic activity occurred during the Sinemurian (synrift deposits of Fantoni \& Scotti, 2003) with the deposition of the Moltrasio Limestone (Upper Hettangian-Sinemurian), which reaches a present-day thickness of more than $3000 \mathrm{~m}$ in western Lombardy (Monte Generoso; Bernoulli, 1964). In the Lombardy Basin, a decrease in the subsidence and tectonic activity in the Late Pliensbachian-Toarcian is recorded by sediments (Sogno Formation and Concesio Formation) that mantled the previous horst and graben paleogeography (Fig.7a).

Data collected in the Biella zone demonstrate that, in the Western Southern Alps, the major episode of subsidence occurred close to the Pliensbachian-Toarcian boundary (asymmetric rift, Fig. 7b) and thus postdate the Jurassic extensional event recorded in th eLombardy Basin (Late Hettangian-Sinemurian).

The onset of the syndepositional tectonic activity is recorded in the Biella-Canavese zones, close to the Pliensbachian-Toarcian boundary, by the deposition of the turbidite layers in the Calcari Spongolitici at M. Fenera and Sostegno (synrift deposits). Evidence for coeval clastic input was also recorded in the Monte Nudo Basin, where the distal fine-grained siliciclastics of the Valmaggiore Fm. were deposited (Klin \& Trmpy,1977).

The Late Pliensbachian-Toarcian rifting stage recorded in the Western Southern Alps is associated with large scale detachment faults that put the upper crust (Serie dei Laghi with its sedimentary cover) into contact with the lower crust (Ivrea-Verbano Zone; Handyetal.,1999), compatible with an asymmetric simple shear model (Lemoine et al., 1987). The exhumation of the lower crust in the Canavese zone (Ferrando etal., 2004) in an extensional regime is responsible for the cooling of the Ivrea-Verbano Zone, to less than 3001C about 180Ma (Hunziker, 1974). This age corresponds to the earlyToarcian (time scale of Gradstein etal., 2004) and is coeval with the Early Jurassic drowning of theMonteFenera andSostegno sections. The exhumation of the Ivrea Verbano Zone mainly occurred during the Early Jurassic along the Pogallo low-angle detachment fault (Hodges \& Fountain, 1984; Schmid et al., 1987; Zinggetal.,1990 and Handyetal.,1999).

The incomplete sedimentary record of the Biella zone does not provide data for the reconstruction of the postEarly Jurassic evolution in this part of the Western Southern Alps. It is only possible to deduce the thickness of the eroded post-Lower Jurassic succession from the thermal maturity of the rocks at the base of the M. Fenera section. Vitrinite reflectance (Fantoni \& Scotti, 2003) indicates a stratigraphic overburden of about $1200 \mathrm{~m}$ at the base of theTriassic succession at Monte Fenera (i.e. about $700 \mathrm{~m}$ of sediments have been eroded, as $500 \mathrm{~m}$ are preserved today). 


\section{Constraints on the rift evolution}

The Western Southern Alps represent a key area for understanding the geodynamic evolution of the western margin of Adria. The Biella and Cusio zones acted as a structural high that bordered the rapidly subsiding

Fig.7. Schematic cross section across the Southern Alps passive margin of Adria during the two Early Jurassic extensional stages. The shift in the extension is clearly recorded by the different age of the synrift deposits in the Lombardy Basin and in the Canaveseand Biella zones. The eastern part of the Biella Zone acted as rift shoulder, but for different rift basins in both stage of extension (1, Montalto Dora; 2, Sostegno; 3, Monte Fenera; 4, Gozzano; 5, Invorio; 6 ,

Monte Nudo Basin; 7, Generoso Basin; 8, Iseo Basin; IZ 5 Ivrea-Verbano Zone).

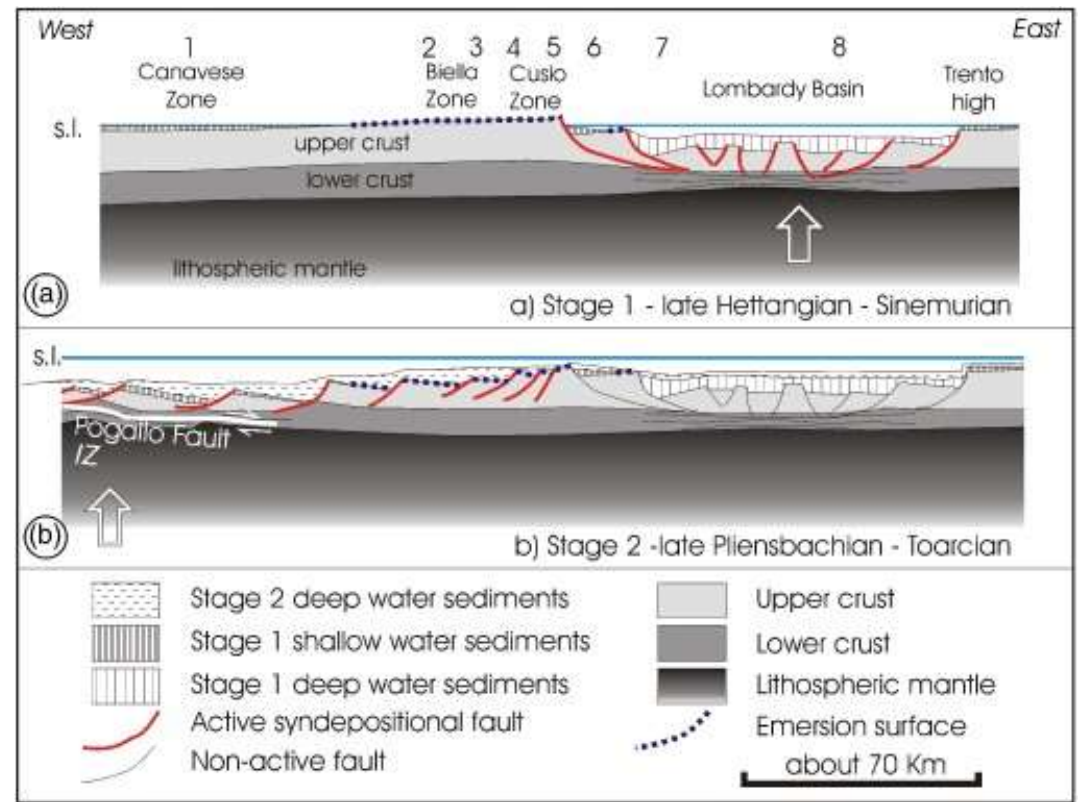




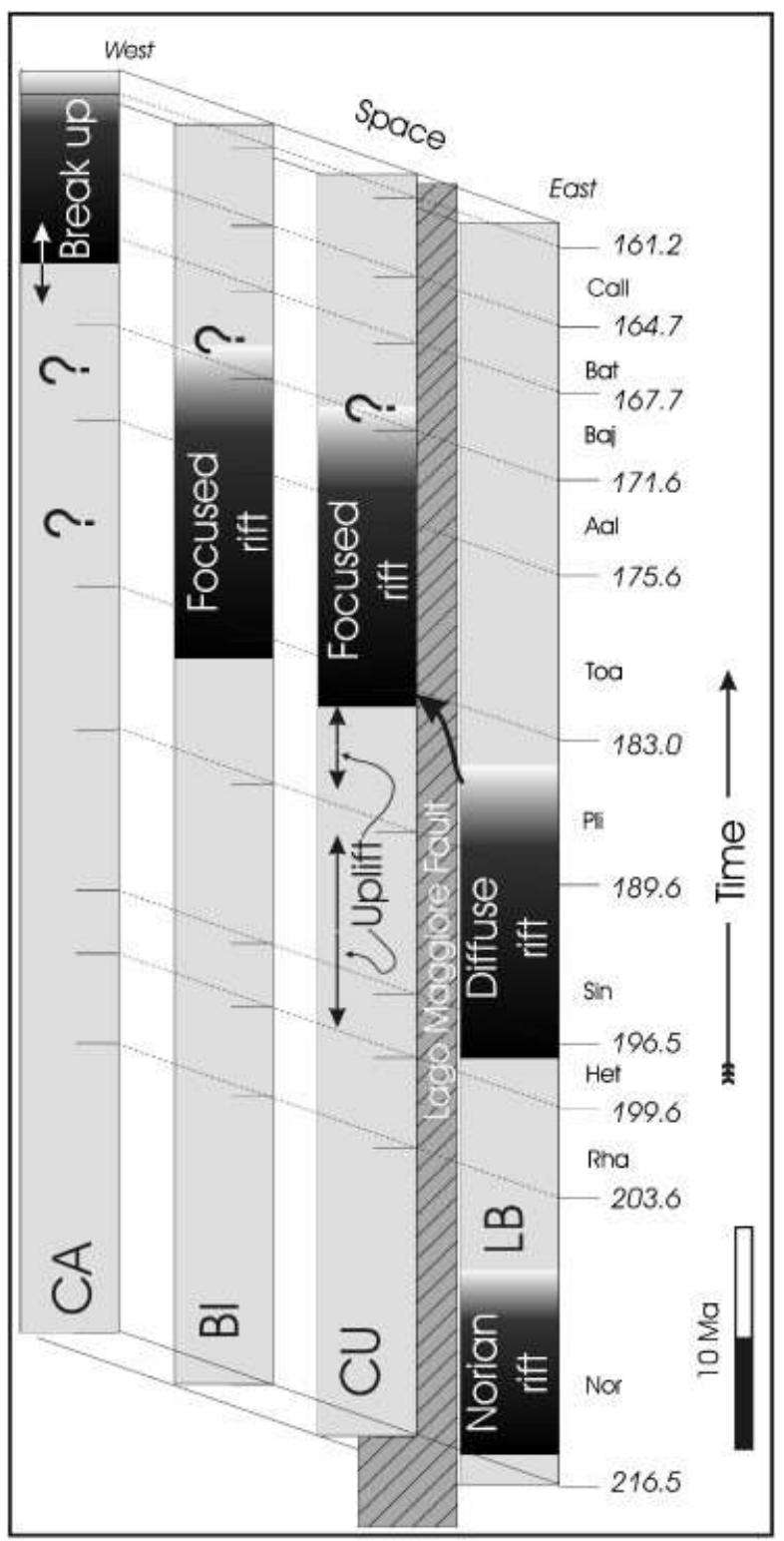

Fig.8. Schematic distribution, in time and space, of the extensional events recorded in the stratigraphic succession along the western margin of Adria in the Southern Alps. LB, Lombardy Basin; CU, Cusio Zone ; BI, Biella Zone ; CA, Canavese zone

Lombardy Basin during Hettangian-Early Sinemurian. During middle to late Early Jurassic the extension migrated westward, causing the post-Pliensbachian drowning of the former rift shoulder(Fig.8).Therefore, two stretching stages (Lavier \& Manatschal, 2006; Manatschal et al., 2007) can be recognized in the Southern Alps. The youngest of these two stages (affecting the Western Southern Alps) evolved into the thinning and exhumation stages and, eventually, to the continental break-up, whereas the oldest stage of stretching was abandoned as extension shifted westward.

Bertotti et al.(1993)and Ferrando et al.(2004)documented the occurrence of two-stage rifting in the Southern Alps characterized by a younger extension in the Western Southern Alps. In the Central Austroalpine region, the existence of two different extensional events on the passive margin of Adria has been demonstrated by Froitzheim \& Manatschal (1996).There, a first symmetrical rifting stage is recorded in the eastern nappes (Hettangian; Ortles Nappe; Eberli, 1988; Froitzheim \& Manatschal, 1996). A second rifting event that would lead to the continental breakup is preserved in the western nappes (ToarcianMiddle Jurassic; Err and Platta Nappes). The strong similarity between the Early Jurassic evolution of the Canavese zone and of the Lower Austroalpine has recently been discussed by Ferrando et al. (2004). 
The first symmetric rifting stage (Lombardy Basin, Late Hettangian-Sinemurian, Fig. 7a) was responsible for the development of the overall symmetric shape of the Lombardy Basin, bounded by eastern (Giudicarie Line) and western (Lake Maggiore Fault) major fault systems (Bertotti etal.,1993). During Late Pliensbachian-Toarcian the extension shifted toward the Western Southern Alps. It is therefore possible to detail the record of the shift in time and space of the rift axis(Bertottietal,1993;Bertotti,2001) within the sedimentary succession of the Western Southern Alps. The extension was responsible for the development of two different, roughly parallel, rifts with a time delay of about 15My (Figs 7 and 8). Late Pliensbachian- Toarcian extension occurred about 25-30Ma before the formation of the oldest documented Penninic (Gets Nappe, Prealps, Switzerland) oceanic crust in late Bajocian (Billetal.,2001).Gabbros that intruded in the Platta nappe (Lower Austroalpine, Platta and Err nappes, Eastern Central Alps, Switzerland) during the latest phase of mantle exhumation along low-angle detachment surfaces were found to be slightly younger (161 1 ; Schaltegger et al., 2002).

The early rift stage also affected the conjugate margin of Adria, i.e. the Dauphined zone. In the Bourg d'Oissant Basin normal faults were responsible for high rates of displacement (about $1800 \mathrm{mMa}^{1}$ ) during Early Sinemurian (Chevalier et al., 2003), synchronous with the maximum subsidence in the Lombardy Basin (Fig.9).

The presence of parallel but not coeval rift basins along the margin of the Penninic Ocean resembles the situation preserved along the western side of the Central and North Atlantic (Fig.9).The Central Atlantic is characterized by an older extensional event (Carnian to Early Jurassic) documented by the continental succession of the Newark Basins that predate the later extension that led, during the Early Jurassic, to the opening of the Atlantic Ocean(Withjacketal.,1998).Data from the Atlantic USA coast indicate a synchronous rift responsible for the development of the Newark Basins (controlled by the reactivation of preexisting faults; Schlische, 2003), followed by a younger and diachronous continental break-up (Withjack \& Schlische, 2005). Also the North Atlantic rift is characterized (on both the American and European sides) by the development of parallel rift basins over a wide area (Jeanne d'Arc,Whale and Horshoe basins on the North American coast; Lusitanian basins and possibly Galicia Interior basins on the European coast; Tucholke et al., 2007). The age of these rift basins (Late Triassic-Early Jurassic) predates the final rifting stage(fromLateJurassic)responsible for the eventual continental break-up (Manatschal \& Bernoulli,1999). 


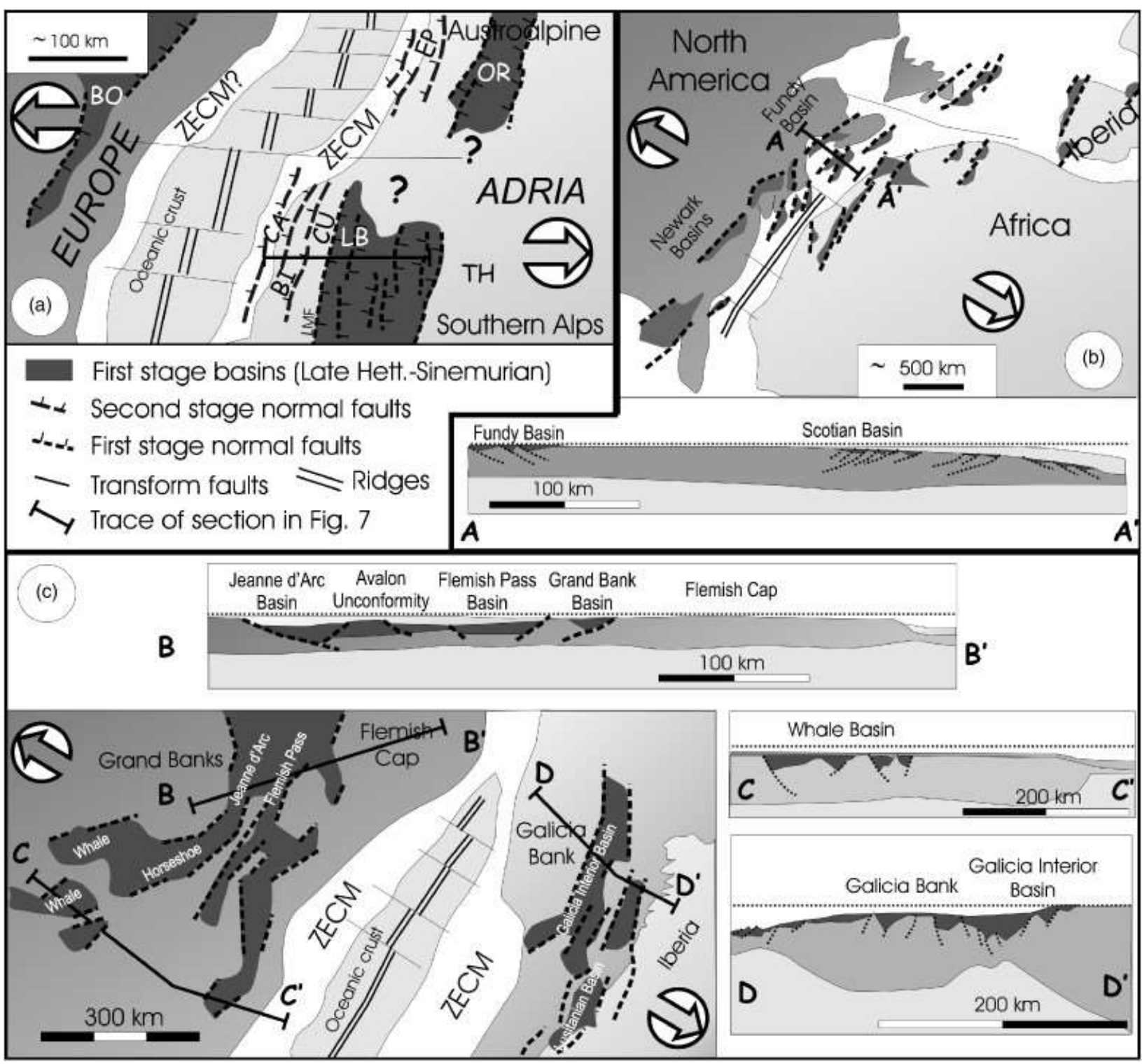

Fig.9. Distribution of early rift basin in the Penninic and North Atlantic Ocean. (a) Schematic reconstruction of the passive margins of Adria, during the opening of the Penninic Ocean. Note the position of the Lombardy Basin (Southern Alps) and of the Ortles Nappe

Basin (Austroalpine) east of the Penninic ocean. CA, Canavese Zone ; BI, Biella Zone ; CU, Cusio Zone, LB, Lombardy Basin; TH,Trento High; OR, Ortles Nappe Basin; BO, Bourg d'Oisan Basin; EP, Platta-Err-Bernina-Ela nappes, LMF, Lago Maggiore Fault, ZECM, zone of exumed continental mantle (modified after Weissert \& Bernoulli, 1985). (b) Schematic reconstruction of the first stages of the opening of the Atlantic Ocean: note the distribution of the Newark Basins on the North American plate, parallel to the spreading axes but older (modified after Keen etal., 1987). Section $A A^{0}$ redrawn from Withjack \& Schlische, 2005. (c) Detail of the North Atlantic conjugate margins of Newfoundland and Iberia (map redrawn from Peron-Pinvidic etal., 2007). ZECM, Zone of Exumed Continental Mantle. Section $\mathrm{BB}^{0}$ redrawn from Perez-Gussiny etal. (2003); $\mathrm{CC}^{0}$ and $\mathrm{DD}^{0}$ redrawn from Keen etal. (1987).

The evolution of the distal passive margin of Adria during the Early Jurassic supports the idea that the major rifting extension which eventually lead to the break-up of a continent is generally predated by long (Bertotti et al., 1993) and diffuse extensional activity responsible for the development of a net of subparallel rift basins.T he transition from a net of subparallel rift basins (rift clusters of Seng $\mathbf{r}$, 1995) to a major rift is reflected along the Adria and the Atlantic margins by the distribution and ages of the synrift sediments. These sediments record how extension focused in the last stages along a major riftvalley. 
The development of rift clusters at the beginning of a rift event is a common feature along the Atlantic, Adria and conjugate margins. The position of the rift basins was very likely favoured by a pre-existing zone of lithospheric weakness, both related to older orogenic belts (i.e. Newark Basins; Schilische, 2003) or to older extensional stages. This is the case for the Ortler Nappe (Berra \& Jadoul, 1999)and of the Lombardy Basin(Jadouletal.,1992)where Norian extensional faults are reactivated during the Early

Jurassic extension. The marginal position of the Lombardy Basin with respect to the future opening of the Pennine Ocean probably led, as extension increased, to the westward shift of the rifting. A time gap ofabout15Mabetween the Toarcian rifting (about 183Ma) and the following spreading (Bajocian, about 168Ma, numeric ages from the timescale of Gradstein et al., 2004) is documented both in the Southern Alps and in the Central Austroalpine (Froitzheim \& Manatschal,1996).

\section{CONCLUSIONS}

Despite poor lateral continuity, the two-stage rift on the distal margin of Adria (Bertotti et al., 1993; Froitzheim \& Manatschal, 1996) can be determined from the stratigraphic evolution of theTriassic-Jurassic succession of the Western Southern Alps. In detail, this zone acted during the older rift event to the east (Hettangian-Sinemurian extension in the Southern Alps) as the rift shoulder of the subsiding Lombardy Basin, whereas it became a subsiding region during the later Late Pliensbachian-Toarcian extension. Our new data on the deposition of the synrift deposits in the Western Southern Alps demonstrate that during the complex and long-lasting rift of Adria the two subsequent rifting events (Bertotti etal.,1993; Froitzheim \&Manatschal,1996)can be clearly constrained in time and space. In detail, the older and wider extension episode became inactive as the new one began.

The presence of extensional basins both on the European (Chevalier et al., 2003) and Adria (i.e. Bosellini, 1973) side of the Penninic Ocean suggests that the extension which lead to the break-up of Adria was accommodated, during the first stages (mainly Sinemurian), by a wide continental zone, where subparallel extensional basins developed. The Hettangian-Sinemurian extension (large basins in the proximal margin; i.e. Bertotti et al., 1993; Froitzheim \& Manatschal,1996) is generally considered to be the beginning of the breakup of Adria, but in the Western Southern Alps it is possible to identify a distinct, major and youngest stretching phase that has been dated as Late Pliensbachian-Early Toarcian. The Late Jurassic break-up occurred as a part of the evolution of this later stage, when the extensional stress focused in a narrow belt, defining a major rift, which eventually led to the opening of the Penninic Ocean. Our data indicate that the late Hettangian-Simenurian rift (i.e. Bertotti et al., 1993; Froitzheim \& Manatschal, 1996) can be interpreted as a preliminary extensional episode and that the beginning of the rifting of Adria from Europe can be identified with the Late Pliensbachian-Toarcian extensional event. This event marks the transition from initial rifting (stretching phase) to thinning, exhumation and spreading (Manatschal, 2004). The stretching phase is characterized by a gradual migration of the deformation toward the ocean until the onset of seafloor spreading (Peron-Pinvidic et al., 2007).

The evolution of the passive margin of Adria shows similarities with the opening of the Central and Northern Atlantic Ocean, where early rift basins are now preserved on both sides of the Ocean (i.e. Withjack et al., 1998; Tucholkeetal., 2007).

Our data indicate that the facies analysis and time-relationships among the different rift successions associated with a continental break-up can, I $\mathrm{n}$ favourable conditions, be reconstructed through outcrop studies. In contrast, the geometry of a rift can be better understood by means of seismic imaging (i.e.Peron-Pinvidic et al., 2007).In this latter case determining the age of the older sediments in the seismic images is often difficult and requires a large amount of direct observations(i.e. drill holes). Once more, the integration of observation from outcropping sections together with seismic imaging is synergic in the reconstruction of the evolution of complex and large-scale geological structures.

\section{ACKNOWLEDGEMENTS}

We are grateful to Daniel Bernoulli for reading a preliminary version of the manuscript and for his recommendations for improving it. This paper benefited by the detailed reviews of Gianreto Manatschal, Niko Froitzheim and an anonymous reviewer. Their comments, as well as those, detailed and precious, of the editor Michelle Kominz, considerably improved the first version of the manuscript. Field work and analyses were funded by COFIN.MIUR(PRIN)2005 -12-2-5190003-9toF.Jadoul. 


\section{References}

Amorosi, A. (1997) Detecting compositional, spatial and temporal attributes of glaucony, a tool for provenance research. Sediment.Geol., 109, 135-153.

Baggio, P. (1963) Sulla presenza di una serie titonico - cretacea nel Canavese s.s. (Prealpi Piemontesi). Atti Dell'Istituto veneto di scienze,lettereedarti, 121, 215-234.

Baggio, P. (1965) Caratteri stratigrafici e strutturali del Canavese s.s. nella zona di Montalto Dora (Ivrea). Mem. Ist. Geol. Min. Univ.Padova, 25, 1-25.

Bernoulli, D. (1964) Zur Geologie des Monte Generoso (Lombardische Alpen). Beitr.Geol.KarteSchweiz., 118, 135.

Bernoulli, D., Bertotti, G. \& Froitzheim, N. (1990) Meso zoic faults and associated sediments in the Austroalpine-South Alpine continental margin. Mem.Soc.Geol.Ital., 45, 25-38.

Bernoulli, D., Caron, C., Homewood, P., Kalin O, . \& Van Stuijvenberg, J. (1979) Evolution of continental margins in the Alps. Schveiz.Mineral.Petrogr.Mitt., 59, 165-170.

Berra, F. \& Jadoul, F. (1996) Norian Serpulid and microbial bioconstructions: implications for the platform evolution in the Lombardy Basin. Facies, 35, 143-162.

Berra, F. \& Jadoul, F. (1999) Stratigraphy, paleogeography and tectonic setting of the Norian succession of the Ortles Nappe (Central Austroalpine, Lombardy, Northern Italy). Mem. Sci. Geol.Padova, 51, 78-89.

Bersezio, R., Jadoul, F. \& Chinaglia, N. (1997) Geological map of the Norian-Jurassic Succession of Southern Alps north of Bergamo. Boll.Soc. Geol.It., 116, 363-378.

Bertotti, G. (2001) Subsidence, deformation, thermal and mechanical evolution of the Mesozoic South-Alpine rifted margin: an analog for Atlantic-type margins. In: Non-volcanicRifting of Continental Margins: A Comparison of Evidence from Land and Sea (Ed. by R.C.L. Wilson, R.B. Whitmarsh, B. Taylor \& N. Froitzheim), Geol.Soc. Lond.Spec.Publ., 187, 125-141.

Bertotti, G., Picotti, V., Bernoulli, D. \& Castellarin, A. (1993) From rifting to drifting: tectonic evolution of the South Alpine upper crust from Triassic to early Cretaceous. Sedim. Geol., 86, 53-76.

Biino, G. \& Compagnoni, R. (1989) The Canavese Zone between the Serra d'Ivrea and Dora Baltea River (Western Alps). EclogaeGeol. Helv., 82, 413- 427.

Bill, M., O'Dogherty, L., Guex, J., Baumgartner, P.O. \& Masson, H. (2001) Radiolarite ages in Alpine-Mediterranean ophiolites: constraints on the oceanic spreading and the Tethys- Atlantic connection. Bull.Geol.Soc.Am., 113, 129-143.

Bosellini, A. (1973) Modello geodinamico e paleotettonico delle Alpi Meridionali durante il Giurassico -Cretacico. Sue possibili applicazioni agli Appennini. In: Moderne vedute sulla Geologia Dell'Appennino (Ed. by B. Accordi), Quad. Dell'AccademiaNazionaledeiLincei183, 163-205.

Bucefalo Palliani, R. \& Mattioli, E. (1998) High resolution potential of the calcareous nannofossils and dinoflagellate cyst integrated biostratigraphy in the Lower Jurassic (late Pliensbachian-lowerToarcian) of Central Italy. J.Micropal., 17, 153-172.

Bucefalo Palliani, R. \& Riding, J.B. (1997) The influence of palaeoenvironmental change on dinoflagellate cyst distribution: an example from the lower and middle Jurassic of Quercy, southwest France. Bull.CentreRech.ElfExplor.Prod., 21, 107-123.

Bucefalo Palliani, R. \& Riding, J.B. (1999) Early Jurassic (Pliensbachian-Toarcian) dinoflagellate migrations and cyst paleoecology in the Boreal and Tethyan realms. Micropaleontology, 45, 201-214.

Bucefalo Palliani, R. \& Riding, J.B. (2003) Biostratigraphy, provincialism and evolution of European Early Jurassic (Pliensbachian to early Toarcian) dinoflagellate cysts. Palynology, 27, 179-214.

Bucefalo Palliani, R., Riding, J.B. \& Torricelli, S. (1997) The dinoflagellate cyst Luehndea Morgenroth, 1970, emend. from the upper Pliensbachian (Lower Jurassic) of Hungary. Rev.Palaeob. Palyn., 96, 113-120.

Carraro, F. \& Fiora, L. (1974) Studio petrografico e stratigrafi co delle tufiti medio -triassiche dei lembi di Crevacuore e Sostegno (Biellese orientale). Riv.It.Paleont.Stratigr., 80, 167-191.

Carraro, F. \& Sturani, C. (1972) Segnalazione di Toarciano fossilifero in facies austroalpina "Fleckenmergeln") nel lembo sedimentario di Sostegno (Biellese). Boll. Soc. Geol. It., 91, 407- 414.

Casati, P. (1978) Tettonismo e sedimentazione nel settore occidentale delle Alpi Meridionali durante il tardo Paleozoico, il Triassico e il Giurassico. Riv.It.Paleont. Stratigr., 84, 313-326.

Chevalier, F., Guiraud, M., Garcia, J.-P., Dommergues,

J.-L., Quesne, D., Allemand, P. \& Dumont, T. (2003) Calculating the long-term displacement rates of a normal fault from the high-resolution stratigraphic record (early Tethyan rifting, French Alps). TerraNova, 15, 410- 416.

Cozzi, A. (2000) Synsedimentary tensional features in Upper Triassic shallow-water platform carbonates of the Carnian Prealps (northern Italy) and their importance as palaeostress indicators. BasinRes., 12, 133-146. 
Cozzi, A. (2002) Facies patterns of a tectonically- controlled Upper Triassic platform- slope carbonate depositional system (Carnian Prealps, Northeastern Italy). Facies, 47, 151-178.

Davies, E.H. (1985) The miospore and dinoflagellate cyst Oppelzonation of the Lias of Portugal. Palynology, 9, 105-132.

Eberli, G.P. (1988) The evolution of the southern continental margin of the Jurassic Tethys Ocean as recorded in the Allgau Formation of the Australpine Nappes of Graubunden (Switzerland). EclogaeGeol.Helv., 81, 175-214.

Elter, G., Elter, P., Sturani, P. \& Weidmann, M. (1966) Sur la prolungation du domaine ligure de l'Apennin dans le Monferrat e les Alpes et sur l'origine de la Nappe de la Simme s.l. des Prealpes romandes et chaiblaisiennes. Bull.Lab. Geol. Min. Geophis et museegeologiquedel'universitedelausanne, 76, 279-377.

Fantoni, R., Fantoni, E. \& De Carlis, A. (2003) L'estensione mesozoica al margine occidentale delle Alpi Meridionali (Piemonte settentrionale, Italia). AttiTic.Sc.Terra., 44, 97-110.

Fantoni, R. \& Scotti, P. (2003) Thermal record of the Mesozoic rifting in the Southern Alps. AttiTicinensiSci.TerraSpec.Ser., 9, 8387.

Farabegoli, E. \& De Zanche,V. (1984) A revision of the Anisian stratigraphy in the Western Southern Alps west of Lake Como. Mem.Sci.Geol., 36, 391- 401.

Fensome, R.A. \& Williams, G.L. (2004) The Lentin and Williams Index of Fossil Dinoflagellates 2004 Edition. Am. Assoc. Stratigr.Palynol.Contrib. Ser., 42, 1-909.

Ferrando, S., Bernoulli, D. \& Compagnoni, R. (2004) The Canavese Zone (internal Western Alps): a distal margin of Adria. Schweiz.Mineral.Petrogr.Mitt., 84, 237-256.

Florineth, D. \& Froitzheim, N. (1994) Transition from continental to oceanic basement in theTasna nappe (Engadine window, Graub_nden, Switzerland): evidence for early Cretaceous opening of the Valais ocean. Schweiz. Mineral. Petrogr. Mitt., 74, 437448.

Froitzheim, N. \& Manatschal, G. (1996) Kinematics of Jurassic rifting, mantle exhumation, and passive-margin formation in the Australpine and Penninic nappes (eastern Switzerland). Geol.Soc.Am.Bull., 108, 1120-1133.

Gaetani, M. (1982) Elementi stratigrafici e strutturali della galleria Bellano -Varenna (Nuova SS 36) (Como). Riv. It. Paleont. Strat., $88,1-10$

Gradstein, F.M., Ogg, J.G., Smith, A.G., Agterberg, F.P., Bleeker, W., Cooper, R.A., Davydov,V., Gibbard, P., Hinnov, L., House, M.R., Lourens, L., Luterbacher, H-P., Mcarthur, J., Melchin, M.J., Robb, L.J., Shergold, J.,Villeneuve, M., Wardlaw, B.R., Ali, J., Brinkhuis, H., Hilgen, F.J., Hooker, J., Howarth, R.J., Knoll, A.H., Laskar,

J., Monechi, S., Powell, J., Plumb, K.A., Raffi, I., R.hl, U., Sadler, P., Sanfilippo, A., Schmitz, B., Shackleton,

N.J., Shields, G.A., Strauss, H.,Van Dam, J.,Veizer, J.,Van Kolfschoten, T.H. \& Wilson, D. (2004) AGeologicTimeScale 2004. Cambridge University Press, Cambridge, 500pp.

Handy, M.R., Franz, L., Heller, F., Janett, B. \& Zurbriggen, R. (1999) Multistage accretion and exhumation of the continental crust (Ivrea crustal section, Italy and Switzerland). Tectonics, 18, 1154-1177.

Hodges, K.V. \& Fountain, D.M (1984) Pogallo Line, South Alps, Northern Italy: an intermediate crustal level, low-angle normal fault ? Geology, 12, 151-155.

Hunziker, J.K. (1974) Rb/Sr and K/Ar age determination and the Alpine Tectonic history of the Western Alps. Mem. Ist. Geol. Min.Univ.Padova, 31, 1-55.

Jadoul, F., Berra, F. \& Frisia, S. (1992) Stratigraphy and paleo geographic evolution of a carbonate platform in an extensional tectonic regime: the example of the Dolomia Principale in Lombardy (Italy). Riv.It.Paleont. Strat., 98, 29- 44.

Jadoul, F., Cirilli, S., Masetti, D., Berra, F., Claps, M. \& Frisia, S. (1994) Norian-Rhaetian stratigraphy and paleogeo graphic evolution of the Lombardy Basin (Bergamasc Alps). Field Trip Guide Book, 15th Regional Meeting IAS, Ischia, April 13-15, 1994, 35pp.

Jadoul, F., Galli, M.T., Berra, F., Cirilli, S., Ronchi, P. \& Paganoni, A. (2004) The Late Triassic-Early Jurassic of the Lombardy Basin: Stratigraphy, Palaeogeography and Palaeontology. 32IGCFlorenceAugust20-28,2004,ExcursionGuidebook, P68, 36pp.

Jadoul, F., Galli, M.T., Calabrese, L. \& Gnaccolini, M. (2005) Stratigraphy of Rhaetian to Lower Sinemurian carbo nate platforms in Western Lombardy (Southern Alps, Italy): paleogeographic implications. Riv.It.Paleont.Strat., 111, 285-303.

Klin, O. \& Tr`mpy, D. (1977) Sedimentation und Paleo tektonik in den westlchen Sudalpen: zur triassich-jurassichen Geschichte des Monte Nudo Beckens. Eclogae Geol. Helv., 70, 295-350.

Keen, C.E., Boutilier, R., Devoogd, B., Mudford, B. \& Enachescu, M.E. (1987) Crustal geometry and extensional models for the Grand Banks, eastern Canada: constraints from deep seismic reflection data. In: Sedimentary Basins and BasinForming Mechanisms (Ed. by C. Beaumont \& A. Tankard), Can.

Soc.Petrol.Geol. 12, 101-115. 
Lavier, L.L. \& Manatschal, G. (2006) A mechanism to thin the continental lithosphere at magma poor margins. Nature, 440, $324-$ 329.

Lemoine, M., Tricart, P. \& Boillot G, . (1987) Ultramafic and gabbroic ocean floor of the Ligurian Tethys (Alps, Corsica, Apennines): in search of a genetic model. Geology, 15,

622- 625

Manatschal, G. (2004) New models for evolution of magmapoor rifted margins based on a review of data and concepts from West Iberia and the Alps. Int.J.Earth. Sci., 93, 432- 466.

Manatschal, G. \& Bernoulli, D. (1999) Architecture and tectonic evolution of non-volcanic margins: present- day Galicia and ancient Adria. Tectonics, 18(6), 1099-1199.

Manatschal, G., Muntener, O., Lavier, L.L., Minshull, T.A. \& Peron-Pinvidic, G. (2007) Observations from the Alpine Tethys and Iberia-Newfoundland margins pertinent to the interpretation of continental breakup. In: Imaging,Mapping and Modelling Continental Lithosphere Extension and Breakup (Ed. by G.D. Karner, G. Manatschal \& L.M. Pinheiro), Geol. Soc. Lond.Spec. Publ. 282, 291-324.

Manatschal, G. \& Nievergelt, P. (1997) A continent- ocean transition recorded in the Err \& Platta nappes (eastern Switzerland). EclogaeGeol.Helv., 90(1), 3-27.

Mattioli, E. \& Erba, E. (1999) Synthesis of calcareous nanno fossil events in Tethyan Lower and Middle Jurassic successions. Riv.Ital.Paleontol.Stratigr., 105, 343-376.

Montanari, L. (1969) Aspetti geologici del Lias di Gozzano (Lago d’Orta). Mem. Soc. It. Sc. Nat. Mus. Civico Storia Nat. Milano, 18, 25-94.

Neuweiler, F. \& Bernoulli, D. (2005) Mesozoic (Lower Jurassic) red stromatactis limestones from the Southern Alps (Arzo, witzerland): calcite mineral authigenesis and syneresis-type deformation. Int. J.Earth.Sci., 94, 130-146.

Perez-Gussiny, M., Ranero, C.R., Reston, T.J. \& Sawyer, D. (2003) Mechanisms of extension at nonvolcanic argins: evidence from the Galicia interior basin, west of Iberia. J. Geophys.Res., 108, 2245, doi 10.1029/2001JB000901.

Peron-Pinvidic, G., Manatschal, G., Minshull, T.A. \& Sawyer, D.S. (2007) Tectonosedimentary evolution of the deep IberiaNewfoundland margins: evidence for a complex breakup history. Tectonics, 26(2), TC2011. (doi: 10.1029/2006TC001970).

Poulsen, N.E. \& Riding, J.B. (2003) The Jurassic dinoflagellate cyst zonation of Subboreal Northwest Europe. Geol.Surv.DenmarkGreenlandBull., 1, 115-144.

Rasetti, G.E. (1897) II Monte Fenera di Valsesia. Boll. Soc. Geol. It., anno XVI, 141pp.

Riding, J.B. \& Thomas, J.E. (1992) Dinoflagellate cysts of the Jurassic system. In: A Stratigraphic Index of Dinoflagellate Cysts (Ed. by A.J. Powell), Br,Micropal.Soc.Publ.Ser., 7-97. Chapman \& Hall, London.

Sacchi Vialli, G. \& Cantaluppi, G.M. (1967) I nuovi fossili di Gozzano. Mem.Soc.It. Sc.Nat.Milano, 16, 238-296.

Schaltegger, U., Desmurs, L., Manatschal, G., M`ntener, O., Meier, M. \& Bernoulli, D. (2002) The transition from rifting to seafloor spreading within a magma-poor rifted margin: field and isotopic constraints. Terra Nova, 14, 156-162.

Schlische, R.W. (2003) Progress in understanding the structural geology, basin evolution, and Tectonic history of the Eastern North American rift system. In: The Great Rift Valleys of Pangea inEasternNorthAmericaVolumeOne:Tectonics,Structure, andVolcanism (Ed. by P.M. LeTourneau \& P.E. Olsen), pp. 21- 64. Co lumbia University Press, New York.

Schmid, S.M., Zingg, A. \& Handy, M. (1987) The kinematics of movements along the Insubric Line and the emplacement of the Ivrea Zone. Tectonophysics, 135, 47- 66.

Seng r, A.M.C. (1995) Sedimentation and tectonics of fossil rifts. In: Tectonics of Sedimentary Basins (Ed. by C.J. Busby \& R.V. Ingersoll), pp. 53-117. Blackwell Science, Oxford.

Sturani, C. (1965) Prima segnalazione di Ammoniti nel Lias del Canavese. Accademia Nazionale Lincei, Rend. Classe Scienze Fisiche,MatematicheeNaturali, fasc. 6, serie 8, 37, 482- 483.

Sturani, C. (1975) Explanatory notes on the Western Alps (from the Sestri-Voltaggio Line to the Val d'Ossola). Structural model of Italy; maps and explanatory notes. Q. "La Ricerca Scientifica”, 90, 149-174.

Tucholke, B.E., Sawyer, D.S. \& Sibuet, J.-C. (2007) Breakup of the Newfoundland - Iberia rift. In: Imaging, Mapping and Modelling Continental Lithosphere Extension and Breakup (Ed. by G.D. Karner, G. Manatschal \& L.M. Pinheiro), Geol.Soc.Lond. Spec.Publ. 282, 9- 46.

Weissert, H.J. \& Bernoulli, D. (1985) A transform margin in the Mesozoic Tethys: evidence from the Swiss Alps. Geol. Runds., 74, 665- 679.

Wiedenmayer, F. (1963) ObereTriass bis mittlerer Lias zwischen Saltrio und Tremona. EclogaeGeol.Helv., 56, 529- 640. 
Wilson, R.C.L., Manatschal, G., Wise, S. \& Urquhart, E. (2001) The location, timing and duration of rifting along nonvolcanic passive margins: evidence from the Mesozoic of the Alps and Western Iberia. In: Imaging, Mapping and Modelling Continental Lithosphere Extension and Breakup (Ed. by G.D. Karner, G. Manatschal \& L.M. Pinheiro), Geol. Soc. Lond. Spec. Publ. 187, 429452.

Winterer, E.L. \& Bosellini, A. (1981) Subsidence and sedimentation on a Jurassic passive continental margin, Southern Alps (Italy). Am.Assoc.PetroleumGeol.Bull., 65, 394- 421.

Withjack, M.O. \& Schlische, R.W. (2005) A review of tectonic events on the passive margin of eastern North America. In: Petroleum Systems of Divergent Continental Margin Basins: 25th BobS.PerkinsResearchConference (Ed. by P. Post), GulfCoastSectionofSEPM, 203-235.

Withjack, M.O., Schlische, R.W. \& Olsen, P.E. (1998) Diachronous rifting, drifting, and inversion on the passive margin of Central Eastern North America: an analog for other passive margins. AAPGBull., 82, 817-835.

Wood, G.D., Gabriel, A.M. \& Lawson, J.C. (1996) Palynological techniques: processing and microscopy. In: Palynology: Principles and Applications (Ed. by J. Jansonius \& D.C. McGregor), Am. Assoc. Stratigr. Palynol.Found. 1, 29-50. Dallas.

Woollam, R. \& Riding, J.B. (1983) Dinoflagellate cyst zonation of the English Jurassic. Inst.Geol. Sci.Rep., 83, 44.

Zingg, A., Handy, M.R., Hunziker, J.C. \& Schmid, S.M. (1990) Tectonometamorphic history of the Ivrea Zone and its relationship to the crustal evolution of the Southern Alps. Tectonophysics, 182, 169-192.

Zingg, A., Hunziker, J.C., Frey, M. \& Ahrendt, H. (1976) Age and degree of metamorphism of the Canavese Zone and the sedimentary cover of the Sesia Zone. Mineral.Petrogr.Mitt., 56, 361-375.

Manuscript received 3 March 2008; Manuscript accepted 18 August2008.

\section{APPENDIX1}

Alphabetical listing of dinoflagellate cysts recovered in the present study. Taxa illustrated are followed by plate and figure references in brackets. The generic allocation and authorship of dinoflagellate cyst species follow Fensome $\&$ Williams (2004).

Luehndeaspinosa Morgenroth,1970

Mancodinium semitabulatum Morgenroth,1970

Mendicodinium spinosum Bucefalo Palliani etal. (1997)

Nannoceratopsis deflandreideflandrei (Evitt,1961) Ilyinaetal., 1994

Nannoceratopsis deflandrei senex (Van Helden, 1977) Ilyina etal.,1994

Nannoceratopsis cf. globiformis Bucefalo Palliani \& Riding (1997)

Nannoceratopsis cf. magnicornus Bucefalo Palliani \& Riding (1997)

Remarks. Specimens recorded in the present study exhibit the prominent, bulbous, distally rounded antapical horn typical of N. magnicornus, but they show neither thinned autophragm nor large subcircular holes in the mid lateral area. Scriniocassis weberi Gocht,1964 